Prepared in cooperation with the Bureau of Reclamation

\title{
Assessment of Dissolved-Selenium Concentrations and Loads in the Lower Gunnison River Basin, Colorado, as Part of the Selenium Management Program, from 2011 to 2016
}

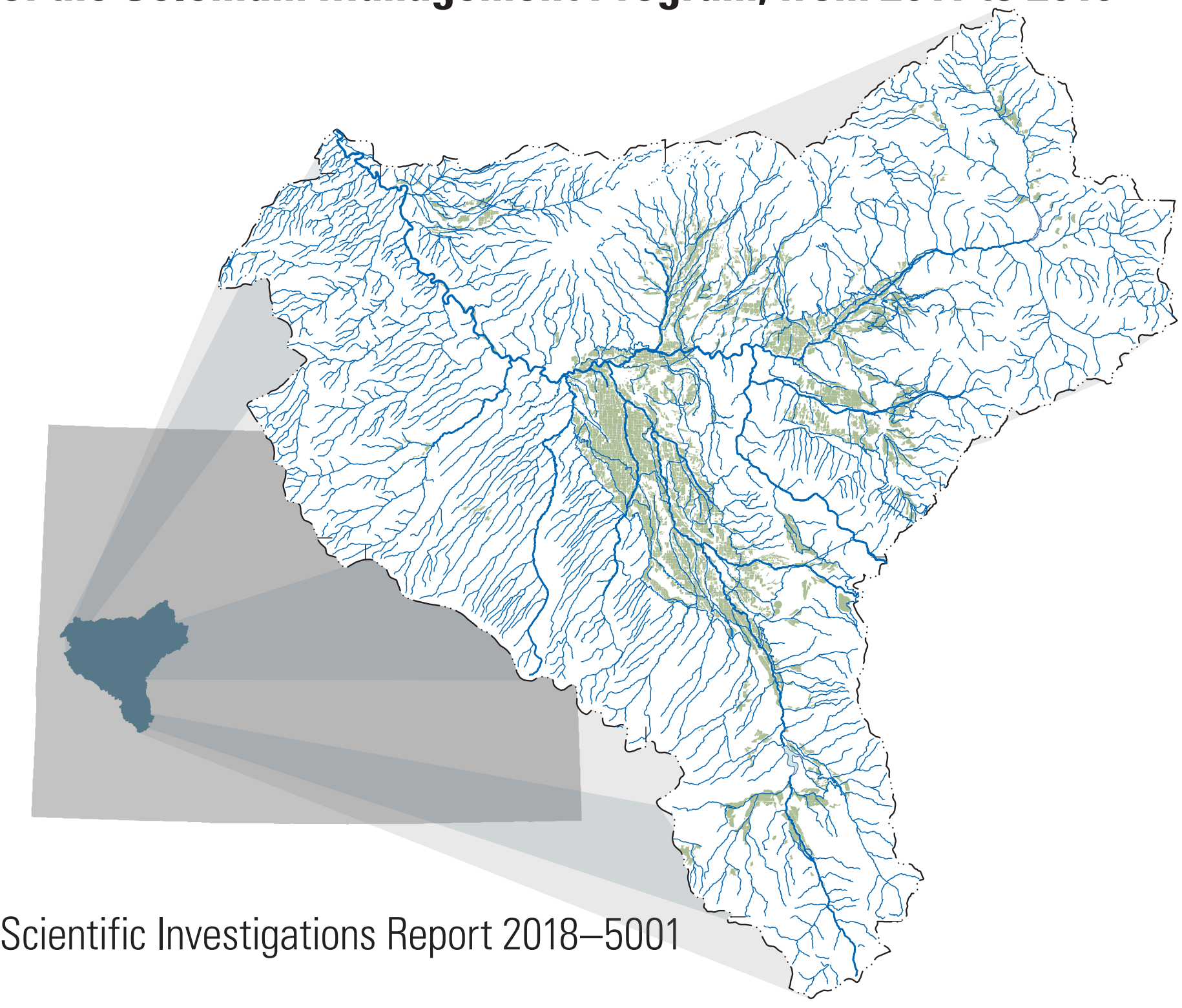


Cover. Map of the lower Gunnison River Basin showing the location of 5 U.S. Geological Survey streamflow-gaging stations and 13 ancillary sites in the LGRB Selenium Management Program. (LGRB, lower Gunnison River Basin; USGS, U.S. Geological Survey.) 


\section{Assessment of Dissolved-Selenium Concentrations and Loads in the Lower Gunnison River Basin, Colorado, as Part of the Selenium Management Program, from 2011 to 2016}

By Mark F. Henneberg

Prepared in cooperation with the Bureau of Reclamation

Scientific Investigations Report 2018-5001 


\title{
U.S. Department of the Interior \\ RYAN K. ZINKE, Secretary
}

\section{U.S. Geological Survey William H. Werkheiser, Deputy Director exercising the authority of the Director}

\author{
U.S. Geological Survey, Reston, Virginia: 2018
}

For more information on the USGS - the Federal source for science about the Earth, its natural and living resources, natural hazards, and the environment-visit https://www.usgs.gov or call 1-888-ASK-USGS.

For an overview of USGS information products, including maps, imagery, and publications, visit https://store.usgs.gov.

Any use of trade, firm, or product names is for descriptive purposes only and does not imply endorsement by the U.S. Government.

Although this information product, for the most part, is in the public domain, it also may contain copyrighted materials as noted in the text. Permission to reproduce copyrighted items must be secured from the copyright owner.

Suggested citation:

Henneberg, M.F., 2018, Assessment of dissolved-selenium concentrations and loads in the lower Gunnison River Basin, Colorado, as part of the Selenium Management Program, from 2011 to 2016: U.S. Geological Survey Scientific Investigations Report 2018-5001, 23 p., https://doi.org/10.3133/sir20185001.

ISSN 2328-0328 (online) 


\section{Contents}

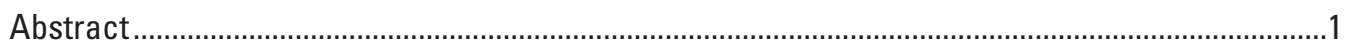

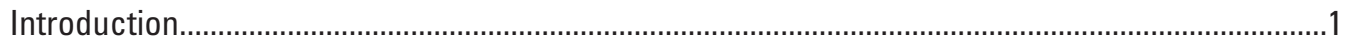

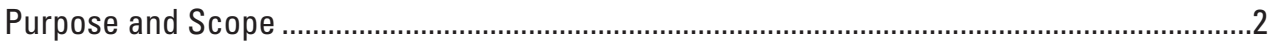

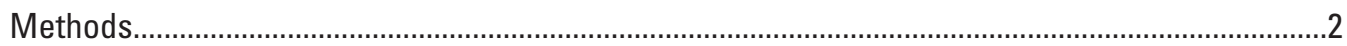

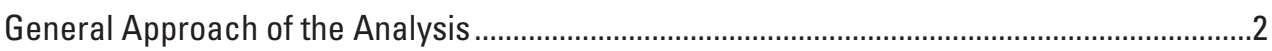

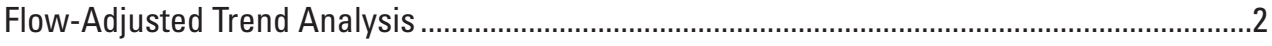

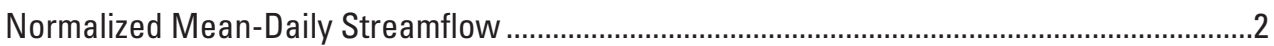

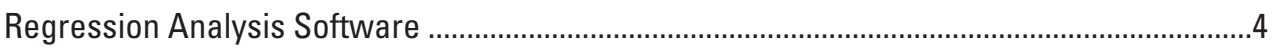

Assessment of Dissolved-Selenium Concentrations and Loads .................................................

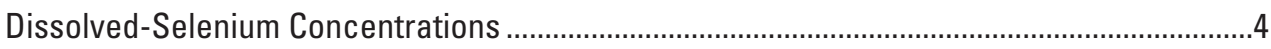

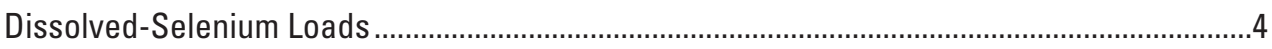

Concentration Percentiles for Dissolved Selenium ..................................................................

Trend Analysis of Dissolved-Selenium Concentrations and Loads................................................

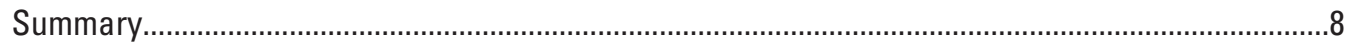

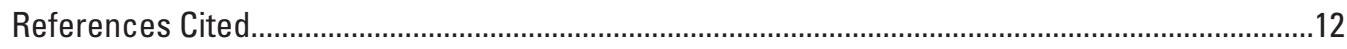

Appendix 1. R-LOADEST Equation Forms, Variable Coefficients,

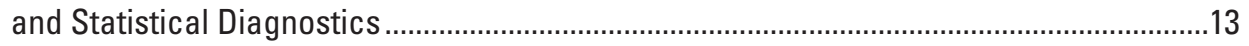

Appendix 2. Calibration Data For 2015 and 2016 Annual Load

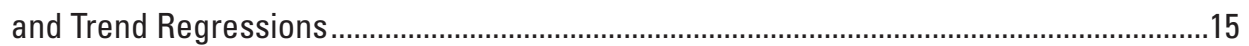

\section{Figures}

1. Map of the lower Gunnison River Basin showing the location of 5

U.S. Geological Survey streamflow-gaging stations and 13 ancillary sites in the LGRB Selenium Management Program

2. Boxplots of dissolved-selenium concentration, in micrograms per liter, for discrete water-quality samples for water years 2011-2016.

3. Boxplots of dissolved-selenium load, in pounds per day, for instantaneous water-quality samples for water years 2011-2016

4. Plot of dissolved-selenium concentration partial residuals and Locally Weighted Scatterplot Smoothing (LOWESS) fit line for Whitewater (09152500) for water years 1986-2016

5. Plot of dissolved-selenium concentration partial residuals and Locally Weighted Scatterplot Smoothing (LOWESS) fit line for Whitewater (09152500) for water years 1994-2016

\section{Tables}

1. Tasks completed at 18 U.S. Geological Survey sites in the lower Gunnison River Basin.

2. Estimated annual dissolved-selenium load, in pounds per year, calculated using multiple linear regression techniques in R-LOADEST (Runkel and others, 2004) at five core sites with U.S. Geological Survey streamflow-gaging stations for water years 2011-2016. 
3. Median and mean instantaneous dissolved-selenium load, in pounds per day, at 18 sites for water years 2011-2016.

4. Changes in median dissolved-selenium loads along the main stem of the Gunnison River based on discrete water-quality samples for water years 2011-2016

5. Estimated dissolved-selenium 85th-percentile concentration, in micrograms per liter, from daily dissolved-selenium loads calculated using multiple linear regression techniques in R-LOADEST (Runkel and others, 2004), at five core sites with U.S. Geological Survey streamflow-gaging stations for water years 2011-2016.

6. Dissolved-selenium 85th-percentile concentrations for 5 core sites with U.S. Geological Survey streamflow-gaging stations and 13 ancillary sites, in micrograms per liter, for discrete water-quality samples collected during water years 2011-2016.

7. Annual dissolved-selenium trend from water year 1986 to water year 2016 at U.S. Geological Survey streamflow-gaging station 09152500, Whitewater.

8. Annual dissolved-selenium trend from water year 1994 to water year 2016 at U.S. Geological Survey streamflow-gaging station 09152500, Whitewater

1.1. Summary of equation forms used to estimate annual dissolved-selenium load for water year 2015 at five core sites with U.S. Geological Survey streamflow-gaging stations in the lower Gunnison River Basin

1.2. Summary of equation forms used to estimate annual dissolved-selenium load for water year 2016 at five core sites with U.S. Geological Survey streamflow-gaging stations in the lower Gunnison River Basin

1.3. Regression model coefficients and statistical diagnostics at five core sites with U.S. Geological Survey streamflow-gaging stations in the lower Gunnison River, water year 2015.

1.4. Regression model coefficients and statistical diagnostics at five core sites with U.S. Geological Survey streamflow-gaging stations in the lower Gunnison River Basin, water year 2016

2.1. Calibration data for annual load regression models at selected U.S. Geological Survey streamflow-gaging stations

2.2. Calibration data for dissolved-selenium trend analysis at U.S. Geological Survey streamflow-gaging station 09152500 - Gunnison River near Grand Junction (Whitewater) for water years 1986-2016. 


\section{Conversion Factors}

U.S. customary units to International System of Units

\begin{tabular}{lcl}
\hline \multicolumn{1}{c}{ Multiply } & By & \multicolumn{1}{c}{ To obtain } \\
\hline foot $(\mathrm{ft})$ & Length & \\
\hline & 0.3048 & meter $(\mathrm{m})$ \\
\hline cubic foot $\left(\mathrm{ft}^{3}\right)$ & Volume & \\
\hline & 0.02832 & cubic meter $\left(\mathrm{m}^{3}\right)$ \\
\hline cubic foot per second $\left(\mathrm{ft}^{3} / \mathrm{s}\right)$ & Flow rate & \\
\hline & 0.02832 & cubic meter per second $\left(\mathrm{m}^{3} / \mathrm{s}\right)$ \\
\hline pound, avoirdupois $(\mathrm{lb})$ & Mass & \\
\hline
\end{tabular}

International System of Units to U.S. customary units

\begin{tabular}{|c|c|c|}
\hline Multiply & By & To obtain \\
\hline \multicolumn{3}{|c|}{ Volume } \\
\hline liter (L) & 0.2642 & gallon (gal) \\
\hline \multicolumn{3}{|c|}{ Mass } \\
\hline $\operatorname{gram}(\mathrm{g})$ & 0.03527 & ounce, avoirdupois (oz) \\
\hline
\end{tabular}

Concentrations of chemical constituents in water are given in micrograms per liter ( $\mu \mathrm{g} / \mathrm{L})$.

Specific conductance is given in microsiemens per centimeter at 25 degrees Celsius $\left(\mu \mathrm{S} / \mathrm{cm}\right.$ at $\left.25^{\circ} \mathrm{C}\right)$.

Water year in this report is defined as the 12-month period from 0ctober 1 through September 30 and is designated by the year in which it ends.

\section{Abbreviations}

EPA U.S. Environmental Protection Agency

LOWESS Locally Weighted Scatterplot Smoothing

NWIS National Water Information System

SMP Selenium Management Program

USGS U.S. Geological Survey

WY water year 



\title{
Assessment of Dissolved-Selenium Concentrations and Loads in the Lower Gunnison River Basin, Colorado, as Part of the Selenium Management Program, from 2011 to 2016
}

\author{
By Mark F. Henneberg
}

\section{Abstract}

The Gunnison Basin Selenium Management Program implemented a water-quality monitoring network in 2011 in the lower Gunnison River Basin in Colorado. Selenium is a trace element that bioaccumulates in aquatic food chains and can cause reproductive failure, deformities, and other harmful effects. This report presents the percentile values of selenium because regulatory agencies in Colorado make decisions based on the U.S. Environmental Protection Agency (EPA) Clean Water Act Section 303(d) that uses percentile values of concentration. Also presented are dissolved-selenium loads at 18 sites in the lower Gunnison River Basin for water years (WYs) 2011-2016 (October 1, 2010, through September 30, 2016). Annual dissolved-selenium loads were calculated for five sites with continuous U.S. Geological Survey (USGS) streamflow-gaging stations. Annual dissolved-selenium loads for WY 2011 through WY 2016 ranged from 179 and 391 pounds (lb) at Uncompahgre River at Colona to 11,100 and 17,300 $\mathrm{lb}$ at Gunnison River near Grand Junction (herein called Whitewater), respectively.

Instantaneous loads were calculated for five sites with continuous U.S. Geological Survey (USGS) streamflow-gaging stations and 13 ancillary sites where discrete water-quality sampling also took place, using discrete water-quality samples and the associated discharge measurements collected during the period. Median instantaneous loads ranged from 0.01 pound per day (lb/d) at Smith Fork near Lazear to $33.0 \mathrm{lb} / \mathrm{d}$ at Whitewater. Mean instantaneous loads ranged from $0.06 \mathrm{lb} / \mathrm{d}$ at Smith Fork near Lazear to $36.2 \mathrm{lb} / \mathrm{d}$ at Whitewater. Most tributary sites in the basin had a median instantaneous dissolved-selenium load of less than $20.0 \mathrm{lb} /$ day. In general, dissolved-selenium loads at Gunnison River main-stem sites showed an increase from upstream to downstream.

The State of Colorado water-quality standard for dissolved selenium of 4.6 micrograms per liter $(\mu \mathrm{g} / \mathrm{L})$ was compared to the 85 th percentiles for dissolved selenium at selected sites. Annual 85th percentiles for dissolved selenium were calculated for the five core sites having USGS streamflow-gaging stations using estimated dissolved-selenium concentrations from linear regression models. The 85 th-percentile concentrations for WYs 2011-2016 based on this method ranged from $0.62 \mu \mathrm{g} / \mathrm{L}$ and $1.1 \mu \mathrm{g} / \mathrm{L}$ at Uncompahgre River at Colona to $12.1 \mu \mathrm{g} / \mathrm{L}$ and $18.7 \mu \mathrm{g} / \mathrm{L}$ at Uncompahgre River at Delta.

The 85th percentiles for dissolved selenium also were calculated for sites with sufficient data using water-quality samples collected during WYs 2011-2016. The annual 85 th-percentile concentrations based on the discrete samples ranged from $0.16 \mu \mathrm{g} / \mathrm{L}$ and $0.17 \mu \mathrm{g} / \mathrm{L}$ at Gunnison River below Gunnison Tunnel to $62.2 \mu \mathrm{g} / \mathrm{L}$ and $170 \mu \mathrm{g} / \mathrm{L}$ at Loutzenhizer Arroyo at North River Road.

A trend analysis was completed for Whitewater to determine if dissolved-selenium loads are increasing or decreasing. The trend analysis indicates a decrease of 9,100 lb from WY 1986 to WY 2016, a 40.8 percent reduction during the time period. The trend analysis for the annual dissolved-selenium load for WY 1994 to WY 2016 indicates a decrease of 6,300 lb per year, or 33.3 percent.

\section{Introduction}

The Gunnison Basin Selenium Management Program is a private/public partnership of concerned parties working together to identify and implement solutions to reduce selenium concentration in the Gunnison and Colorado Rivers (Bureau of Reclamation, 2011). Selenium is a trace element that bioaccumulates in aquatic food chains and can cause reproductive failure, deformities, and other harmful effects (Hamilton, 1998; Lemly, 2002). The primary goal of the Selenium Management Program (SMP), as recommended in the U.S. Fish and Wildlife Service's "Gunnison River Basin Programmatic Biological Opinion" (U.S. Fish and Wildlife Service, 2009), is to meet the State of Colorado water-quality standard for dissolved selenium of 4.6 micrograms per liter $(\mu \mathrm{g} / \mathrm{L})$ at the U.S. Geological Survey (USGS) streamflow-gaging station number 09152500 — Gunnison River near Grand Junction, 
herein referred to as "Whitewater." A parallel goal is to continue implementation, monitoring, and evaluation of management practices that will maintain or continue to reduce dissolvedselenium concentration in the river. Mayo and Leib (2012) documented a downward trend in dissolved-selenium load from 1986 to 2008 at the Whitewater gage. The SMP's long-term objective is to improve water quality by reducing dissolvedselenium concentrations sufficiently to assist in the recovery of the Colorado pikeminnow (Ptychocheilus lucius) and razorback sucker (Xyrauchen texanus) (Bureau of Reclamation, 2011).

The SMP implemented a water-quality monitoring network in 2011 at 18 USGS sites (5 with streamflow-gaging stations) in the lower Gunnison River Basin (Bureau of Reclamation, 2011). The USGS had also previously collected water-quality data at several of the 18 sites prior to operation of the SMP network. The USGS, in cooperation with the Bureau of Reclamation, has completed a review of dissolved-selenium data from the 18 sites (fig.1) during water years (WYs) 2011-2016 (October 1, 2010, through September 30, 2016) that included the following four types of analyses, which are further broken down into five tasks (A through E) (table 1).

1. Task A. Annual dissolved-selenium loading analyses using linear regression models within R-LOADEST at five core sites with continuous USGS streamflow-gaging stations.

2. Task B. Instantaneous dissolved-selenium loading analyses at 5 core and 13 ancillary sites where discrete waterquality sampling takes place. Instantaneous dissolvedselenium load can be calculated if the dissolved-selenium sample was accompanied by a streamflow measurement.

3. Tasks C and D. Annual (C) and instantaneous (D) 85thpercentile analyses for dissolved selenium at all 18 sites.

4. Task E. Trend analysis of dissolved-selenium concentration and load at Whitewater.

\section{Purpose and Scope}

This report presents the percentile values of selenium concentrations and dissolved-selenium loads at 18 sites in the lower Gunnison River Basin for WYs 2011-2016. Trend analyses of selenium concentration and load also are presented for WY 1986 to WY 2016 and from WY 1994 to WY 2016. The latter trend period is used to focus on recently collected data.

\section{Methods}

This section of the report discusses the technique of flowadjusted trend analysis, the methods used for regression analysis, and the use of regression analysis software in the study. The concept of normalized streamflow is explained, and the estimation of load and concentration trends is shown. Streamflow and water-quality data are available in the USGS National Water Information System (https://doi.org/10.5066/F7P55KJN).

\section{General Approach of the Analysis}

Regression analysis is a long-accepted and widely used method for analyzing trends in water-quality constituents (Kircher and others, 1984; Butler, 1996; Richards and Leib, 2011). Variables selected to estimate trends in water-quality constituents in these types of studies commonly include daily streamflow, time, and measured constituent (selenium for this assessment) values. Various transformations are commonly used to enhance estimation accuracy (logarithmic [log] transformation, quadratic terms, decimal time, centered time, and sinusoidal transformations of time). For this study, daily streamflow, decimal time, and various transformations were used in estimating trends in selenium load and concentration (Mayo and Leib, 2012). Calibration datasets included the current and previous water year's streamflow, specific conductance, and dissolved-selenium concentration for each discrete water-quality sample collected.

\section{Flow-Adjusted Trend Analysis}

Trends in loads and concentrations of water-quality constituents can be approached from two perspectives: nonflow-adjusted (which shows the overall influence from both human and natural factors) and flow-adjusted (which removes natural streamflow variability and emphasizes human-caused influences) (Sprague and others, 2006). Only flow-adjusted trend analyses were carried out in this study because the effect of selenium-control efforts over the study period was of primary interest to the cooperator (Mayo and Leib, 2012).

\section{Normalized Mean-Daily Streamflow}

Daily streamflow values were averaged to produce a mean-daily streamflow (Qn) for each day of the calendar year over the 31-year period of record. An averaging function available on the USGS National Water Information System (NWIS) website (https://doi.org/10.5066/F7P55KJN) was used to calculate these normalized mean-daily streamflow values. For example, an average of all the January 1 daily streamflow values was calculated for January 1, 1986, through January 1, 2016. This creates a Qn value for January 1 over the 31-year period. By calculating a similar Qn for every day of the year, the year-to-year fluctuations in daily streamflow are removed when computing daily selenium loads. The Qn was only used to compare the changes in selenium load and concentration between WY 1986 and WY 2016. It is important to remember that because the estimated loads and concentrations given for WY 1986 and WY 2016 were based on normalized streamflow, the results were only illustrative of the change in selenium loads and concentrations over the period of study. They were not the actual loads and concentrations that occurred in WY 1986 and WY 2016 (Mayo and Leib, 2012). 


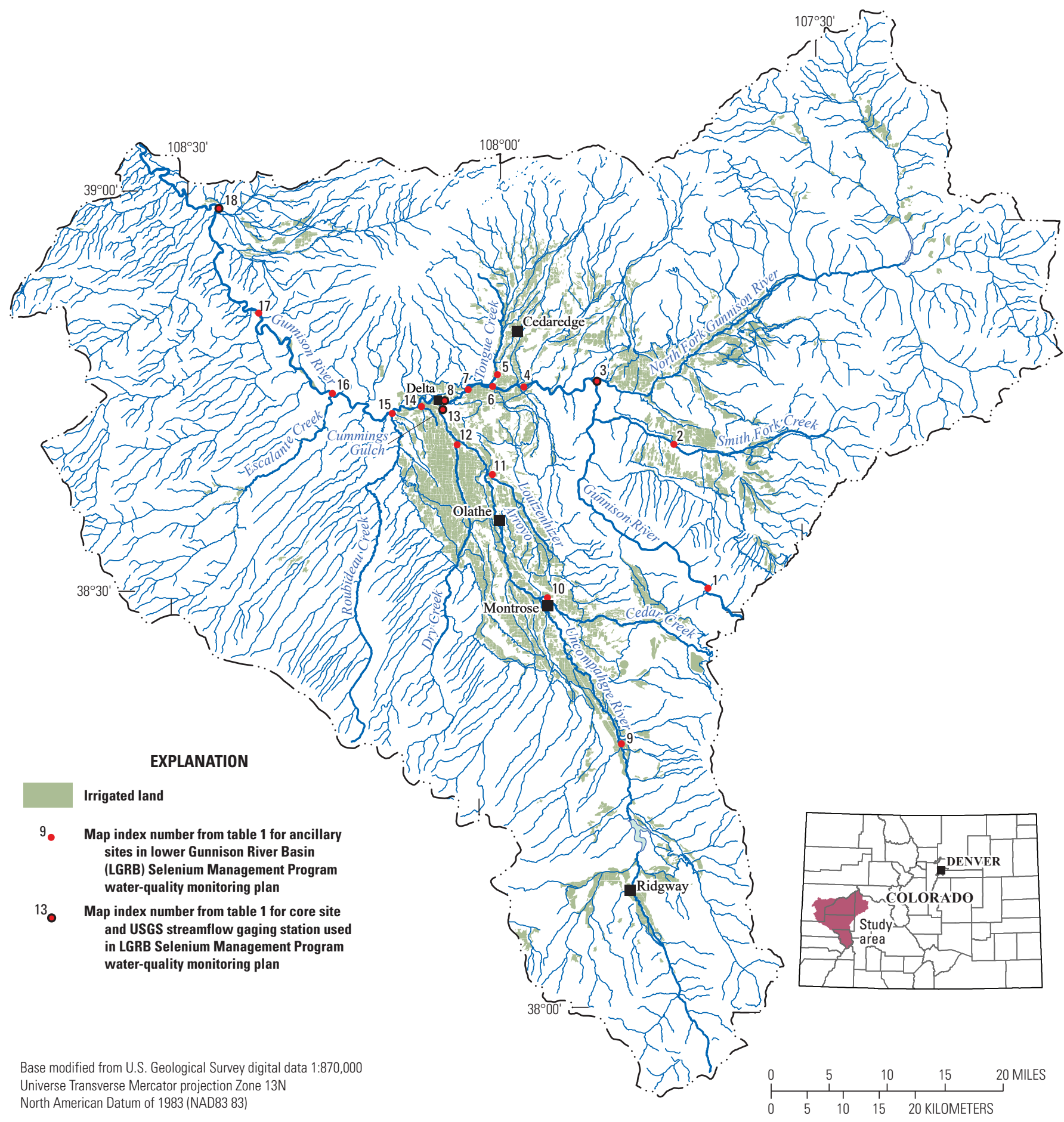

Figure 1. Map of the lower Gunnison River Basin showing the location of 5 U.S. Geological Survey streamflow-gaging stations and 13 ancillary sites in the LGRB Selenium Management Program. (LGRB, lower Gunnison River Basin; USGS, U.S. Geological Survey). 
Table 1. Tasks completed at 18 U.S. Geological Survey sites in the lower Gunnison River Basin.

[Tasks are (A) annual dissolved-selenium loading analysis, (B) instantaneous dissolved-selenium loading analysis, (C) annual dissolved-selenium 85thpercentile estimation, (D) instantaneous dissolved-selenium 85th-percentile estimation, and (E) trend analysis of dissolved-selenium concentration and load at Whitewater. USGS, U.S. Geological Survey]

\begin{tabular}{cllc}
\hline $\begin{array}{c}\text { Map index } \\
\text { number } \\
\text { (fig. 1) }\end{array}$ & \multicolumn{1}{c}{ USGS station short name (USGS station number) } & Site type & $\begin{array}{c}\text { Analysis } \\
\text { types (tasks) }\end{array}$ \\
\hline 1 & Gunnison River below Gunnison Tunnel (09128000) (Sampling terminated after water year 2012) & Ancillary & B, D \\
\hline 2 & Smith Fork near Lazear (09129600) & Ancillary & B, D \\
\hline 3 & North Fork Gunnison River near Lazear (09136100) & Core & A, B, C \\
\hline 4 & Gunnison River at Austin (384624107570701) & Ancillary & B, D \\
\hline 5 & Tongue Creek at Cory (09144200) & Ancillary & B, D \\
\hline 6 & Gunnison River near Cory (09137500) & Ancillary & B, D \\
\hline 7 & Gunnison River near Hartland Dam (384617108022901) & Ancillary & B, D \\
\hline 8 & Gunnison River at Delta (09144250) & Core & A, B, C \\
\hline 9 & Uncompahgre River at Colona (09147500) & Core & A, B, C \\
\hline 10 & Cedar Creek near Mouth (383041107544201) & Ancillary & B, D \\
\hline 11 & Loutzenhizer Arroyo at North River Road (383946107595301) & Ancillary & B, D \\
\hline 12 & Dry Creek at Mouth near Delta (384202108032001) & Ancillary & B, D \\
\hline 13 & Uncompahgre River at Delta (09149500) & Core & A, B, C \\
\hline 14 & Cummings Gulch at Mouth (384448108070301) & Ancillary & B, D \\
\hline 15 & Roubideau Creek near Mouth (09150500) & Ancillary & B, D \\
\hline 16 & Gunnison River above Escalante Creek (384527108152701) & Ancillary & B, D \\
\hline 17 & Gunnison River below Dominguez Creek (385011108225401) & Ancillary & B, D \\
\hline 18 & Whitewater (09152500) & Core & A, B, C, E \\
\hline & & &
\end{tabular}

\section{Regression Analysis Software}

To build the regression model, the software program R-LOADEST was selected because it is designed to calculate constituent loads using daily streamflow, time, seasonality, and other explanatory variables. R-LOADEST was derived from LOADEST (Runkel and others, 2004). R-LOADEST was used to calculate daily selenium loads and concentrations from measured selenium-concentration calibration data spanning WY 1986 through WY 2016 (Mayo and Leib, 2012).

\section{Assessment of Dissolved-Selenium Concentrations and Loads}

\section{Dissolved-Selenium Concentrations}

Boxplots of dissolved-selenium concentrations in water-quality samples are plotted from left to right in an upstream to downstream order for WYs 2011-2016 in figure 2. In general, the dissolved-selenium concentration increased from upstream to downstream at Gunnison River main-stem sites (blue boxes in fig. 2; Uncompahgre
River at Delta is designated a Gunnsion River main-stem site to conform with previous selenium studies in the area). Dissolved-selenium concentrations at most sites ranged from $1.0 \mu \mathrm{g} / \mathrm{L}$ to $10.0 \mu \mathrm{g} / \mathrm{L}$. Gunnison River below Gunnison Tunnel had the lowest dissolved-selenium concentrations (less than $1.0 \mu \mathrm{g} / \mathrm{L}$ ) for all samples, and Loutzenhizer Arroyo at North River Road had the highest (greater than $100 \mu \mathrm{g} / \mathrm{L})$.

\section{Dissolved-Selenium Loads}

Annual dissolved-selenium loads in pounds per year $(\mathrm{lb} / \mathrm{yr})$ for the five core sites are summarized in table 2. Annual load estimates for WY 2011 through 2016 were lowest at the Uncompahgre River at Colona (179 lb/yr to $391 \mathrm{lb} / \mathrm{yr})$ and highest at Whitewater $(11,100 \mathrm{lb} / \mathrm{yr}$ to $17,300 \mathrm{lb} / \mathrm{yr})$. Uncompahgre River at Delta and Gunnison River at Delta contributed 66,100 cumulative pounds out of the 78,600 cumulative pounds at Whitewater during the 6-year monitoring period, suggesting the region between Delta and Whitewater contributed approximately 12,500 cumulative pounds. Equation forms, regression model coefficients, diagnostics, and calibration datasets are provided in appendixes 1 and 2. 


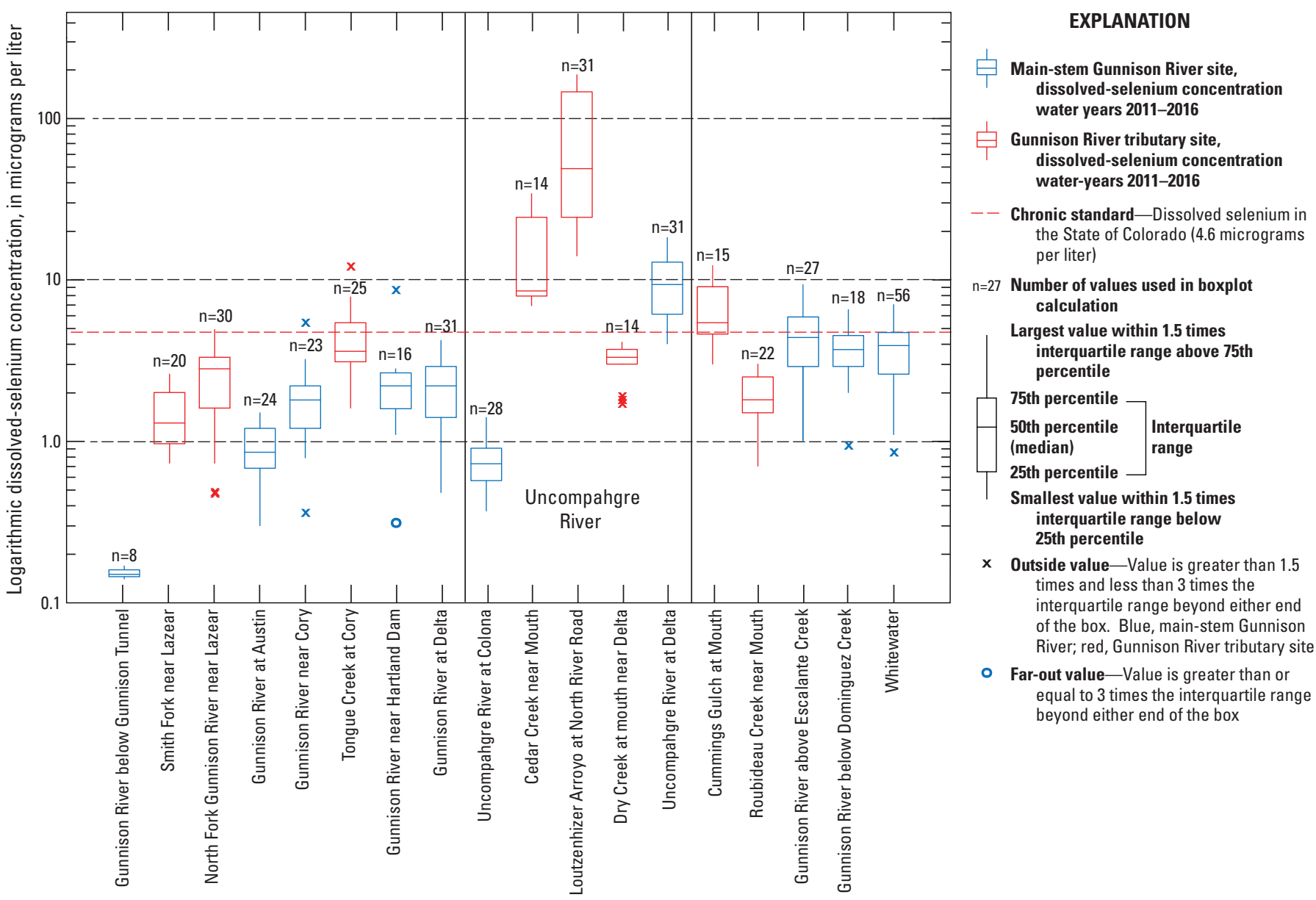

Figure 2. Boxplots of dissolved-selenium concentration, in micrograms per liter, for discrete water-quality samples for water years 2011-2016

Table 2. Estimated annual dissolved-selenium load, in pounds per year, calculated using multiple linear regression techniques in R-LOADEST (Runkel and others, 2004) at five core sites with U.S. Geological Survey streamflow-gaging stations for water years 2011-2016.

[USGS, U.S. Geological Survey; WY, water year, defined as the 12-month period from October 1 through September 30 and designated by the year in which it ends; lb, pound; yr, year]

\begin{tabular}{|c|c|c|c|c|c|c|c|c|}
\hline \multirow{2}{*}{$\begin{array}{c}\text { Map } \\
\text { index } \\
\text { number }\end{array}$} & \multirow{2}{*}{$\begin{array}{l}\text { USGS station } \\
\text { number }\end{array}$} & \multicolumn{6}{|c|}{ Annual dissolved-selenium load (lbs/yr) } & \multirow{2}{*}{$\begin{array}{l}\text { Total dissolved-selenium } \\
\text { load for WYs 2011-2016 } \\
\text { (Ib) }\end{array}$} \\
\hline & & $\begin{array}{l}\text { WY } \\
2011^{1}\end{array}$ & $\begin{array}{l}\text { WY } \\
\text { 2012 }\end{array}$ & $\begin{array}{l}\text { WY } \\
2013^{1}\end{array}$ & $\begin{array}{l}\text { WY } \\
2014^{1}\end{array}$ & $\begin{array}{l}\text { WY } \\
2015\end{array}$ & $\begin{array}{l}\text { WY } \\
2016\end{array}$ & \\
\hline 3 & 09136100 & 1,580 & 1,050 & 967 & 1,220 & 1,250 & 910 & 6,980 \\
\hline 8 & 09144250 & 5,880 & 4,920 & 4,130 & 4,540 & 5,080 & 4,850 & 29,400 \\
\hline 9 & 09147500 & 391 & 194 & 179 & 336 & 348 & 307 & 1,760 \\
\hline 13 & 09149500 & 7,920 & 4,860 & 4,850 & 7,190 & 6,270 & 5,610 & 36,700 \\
\hline 18 & 09152500 & 17,300 & 12,800 & 11,100 & 13,300 & 12,200 & 11,900 & 78,600 \\
\hline
\end{tabular}

${ }^{1}$ Values from Henneberg, 2016. 
Median and mean instantaneous dissolved-selenium loads, in pounds per day $(\mathrm{lb} / \mathrm{d})$, for all 18 sites were calculated using discrete water-quality samples and the associated discharge measurements (table 3). Median instantaneous loads ranged from $0.01 \mathrm{lb} / \mathrm{d}$ at Smith Fork near Lazear to $33.0 \mathrm{lb} / \mathrm{d}$ at Whitewater. Mean instantaneous loads ranged from $0.06 \mathrm{lb} / \mathrm{d}$ at Smith Fork near Lazear to $36.2 \mathrm{lb} / \mathrm{d}$ at Whitewater. Because there were no dissolvedselenium samples collected since WY 2012 at Gunnison River below Gunnison Tunnel, the calculations for median and mean dissolved-selenium loads include WYs 2011 and 2012 only. Loutzenhizer Arroyo at North River Road, with a median dissolved-selenium load of $10.4 \mathrm{lb} / \mathrm{d}$, contributed 31.5 percent of the median load at Whitewater $(33.0 \mathrm{lb} / \mathrm{d})$ during the period WY 2011 through WY 2016. Gunnison River at Delta, with a median dissolved-selenium load of $12.7 \mathrm{lb} / \mathrm{d}$, contributed 38.5 percent during the same period.

Most sites in the basin had a median dissolvedselenium load of less than $20.0 \mathrm{lb} / \mathrm{d}$. In general, dissolved-selenium loads at main-stem Gunnison River sites increased from upstream to downstream (fig. 3).

Changes in median instantaneous dissolved-selenium load between selected sites along the main-stem Gunnison River are reported in table 4. The largest increase in dissolved-selenium load occurred between Gunnison River at Delta and Gunnison River above Escalante Creek; the increase is due to the Uncompahgre River, which contributes approximately $16.6 \mathrm{lb} / \mathrm{d}$ of dissolved selenium in this reach. A previous study reported a slight decrease $(1.8 \mathrm{lb} / \mathrm{d})$ from 2011 to 2014 in dissolved-selenium load between Gunnison River above Escalante Creek and Whitewater (Henneberg, 2016), which was not observed when the WY 2015-2016 samples were included in the dataset. Gunnison River above Escalante Creek had 14 additional samples, and Whitewater had 23, during WYs 2015 and 2016. The dissolved-selenium load increased between these two sites by $1.4 \mathrm{lb} / \mathrm{d}$.

Table 3. Median and mean instantaneous dissolved-selenium load, in pounds per day, at 18 sites for water years $2011-2016$.

[USGS, U.S. Geological Survey; WY, water year, defined as the 12-month period from October 1 through September 30 and designated by the year in which it ends; $1 \mathrm{~b} / \mathrm{d}$, pound per day]

\begin{tabular}{|c|c|c|c|c|c|c|}
\hline $\begin{array}{c}\text { Map index } \\
\text { number } \\
\text { (fig. 1) }\end{array}$ & USGS station number & USGS station short name & $\begin{array}{l}\text { Site } \\
\text { type }\end{array}$ & $\begin{array}{l}\text { Number of } \\
\text { samples WYs } \\
2011-2016\end{array}$ & $\begin{array}{c}\text { Median selnium load } \\
\text { for sample years } \\
\text { (lb/d) }\end{array}$ & $\begin{array}{l}\text { Mean selenium load } \\
\text { for sample years } \\
\text { (lb/d) }\end{array}$ \\
\hline 1 & 09128000 & $\begin{array}{l}\text { Gunnison River below } \\
\text { Gunnison Tunnel }\end{array}$ & A & $8^{1}$ & 0.57 & 1.2 \\
\hline 2 & 09129600 & Smith Fork near Lazear & A & 20 & 0.01 & 0.06 \\
\hline 3 & 09136100 & $\begin{array}{l}\text { North Fork Gunnison River } \\
\text { near Lazear }\end{array}$ & $\mathrm{C}$ & 30 & 2.7 & 3.4 \\
\hline 4 & 384624107570701 & Gunnison River at Austin & A & 24 & 3.9 & 5.2 \\
\hline 5 & 09144200 & Tongue Creek at Cory & A & 25 & 0.56 & 0.70 \\
\hline 6 & 09137500 & Gunnison River near Cory & A & 23 & 8.1 & 9.4 \\
\hline 7 & 384617108022901 & $\begin{array}{l}\text { Gunnison River near Hartland } \\
\text { Dam }\end{array}$ & A & 16 & 8.6 & 10.6 \\
\hline 8 & 09144250 & Gunnison River at Delta & $\mathrm{C}$ & 31 & 12.7 & 14.3 \\
\hline 9 & 09147500 & Uncompahgre River at Colona & $\mathrm{C}$ & 28 & 0.43 & 0.77 \\
\hline 10 & 383041107544201 & Cedar Creek near Mouth & A & 14 & 3.5 & 3.5 \\
\hline 11 & 383946107595301 & $\begin{array}{l}\text { Loutzenhizer Arroyo at North } \\
\text { River Road }\end{array}$ & A & 31 & 10.4 & 12.2 \\
\hline 12 & 384202108032001 & Dry Creek at mouth nr Delta & A & 14 & 1.3 & 1.2 \\
\hline 13 & 09149500 & Uncompahgre River at Delta & $\mathrm{C}$ & 31 & 16.6 & 16.8 \\
\hline 14 & 384448108070301 & Cummings Gulch at Mouth & A & 15 & 1.0 & 0.80 \\
\hline 15 & 09150500 & Roubideau Creek near Mouth & A & 22 & 0.48 & 0.53 \\
\hline 16 & 384527108152701 & $\begin{array}{l}\text { Gunnison River above } \\
\text { Escalante Creek }\end{array}$ & A & 27 & 31.6 & 34.1 \\
\hline 17 & 385011108225401 & $\begin{array}{l}\text { Gunnison River below } \\
\text { Dominguez Creek }\end{array}$ & A & 18 & 32.1 & 31.7 \\
\hline 18 & 09152500 & Whitewater & $\mathrm{C}$ & 56 & 33.0 & 36.2 \\
\hline
\end{tabular}

${ }^{1}$ Only includes samples collected in 2011-2012. 


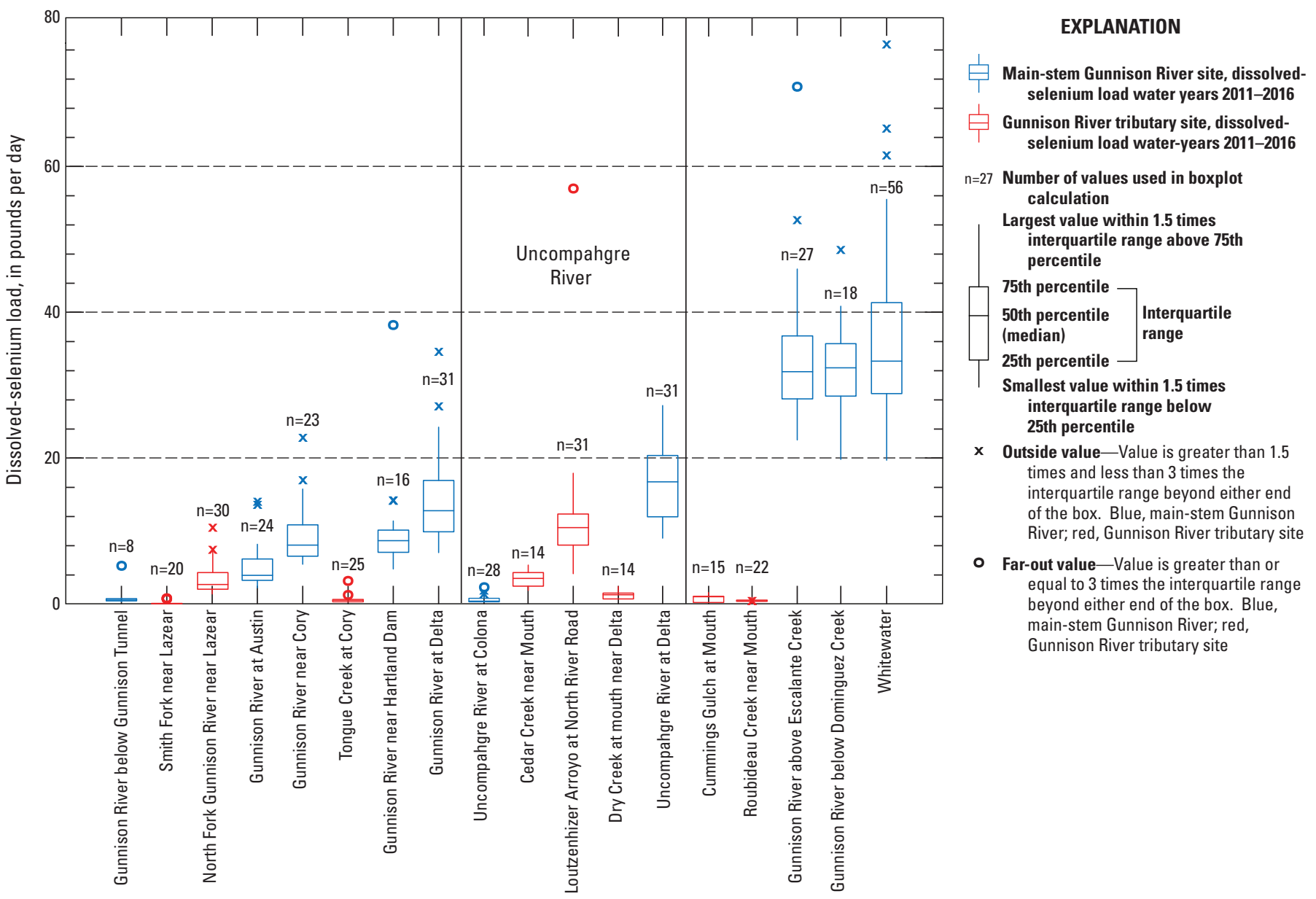

Figure 3. Boxplots of dissolved-selenium load, in pounds per day, for instantaneous water-quality samples for water years 2011-2016.

Table 4. Changes in median dissolved-selenium loads along the main stem of the Gunnison River based on discrete water-quality samples for water years 2011-2016.

[USGS, U.S. Geological Survey; WY, water year, defined as the 12-month period from October 1 through September 30 and designated by the year in which it ends; $1 \mathrm{~b} / \mathrm{d}$, pound per day]

\begin{tabular}{|c|c|c|c|c|c|}
\hline $\begin{array}{l}\text { Map index } \\
\text { number } \\
\text { (fig. 1) }\end{array}$ & $\begin{array}{l}\text { USGS station } \\
\text { number }\end{array}$ & USGS station short name & $\begin{array}{l}\text { Number of } \\
\text { samples WYs } \\
\text { 2011-2016 }\end{array}$ & $\begin{array}{c}\text { Median selenium } \\
\text { load for 2011-2016 } \\
\text { (lb/d) }\end{array}$ & $\begin{array}{l}\text { Change in median } \\
\text { dissolved-selenium } \\
\text { load between stations } \\
\text { for 2011-2016 } \\
\text { (Ib/d) }\end{array}$ \\
\hline \multirow[t]{2}{*}{4} & 384624107570701 & Gunnison River at Austin & 24 & 3.9 & \\
\hline & & & & & 4.2 \\
\hline \multirow[t]{2}{*}{6} & 09137500 & Gunnison River near Cory & 23 & 8.1 & \\
\hline & & & & & 0.5 \\
\hline \multirow[t]{2}{*}{7} & 384617108022901 & Gunnison River near Hartland Dam & 16 & 8.6 & \\
\hline & & & & & 4.1 \\
\hline \multirow[t]{2}{*}{8} & 09144250 & Gunnison River at Delta & 31 & 12.7 & \\
\hline & & & & & 18.9 \\
\hline \multirow[t]{2}{*}{16} & 384527108152701 & Gunnison River above Escalante Creek & 27 & 31.6 & \\
\hline & & & & & 1.4 \\
\hline 18 & 09152500 & Whitewater & 56 & 33.0 & \\
\hline
\end{tabular}




\section{Concentration Percentiles for Dissolved Selenium}

The 85th percentile values of estimated selenium concentration were calculated for WY 2011 through WY 2016. This report presents the percentile values of selenium because regulatory agencies in Colorado make decisions based on the U.S. Environmental Protection Agency (EPA) Clean Water Act Section 303(d) that uses percentile values of concentration (Mayo and Leib, 2012). The 85th-percentile concentrations for dissolved selenium were derived for the 18 sites for WYs 2011-2016 with the exception of Gunnison River below Gunnison Tunnel (09128000), which only had data for WYs 2011-2012. The 85th percentiles presented in table 5 for the five core sites were estimated as part of the R-LOADEST daily load calculations as described by Mayo and Leib (2012). The 85th percentiles for all 18 sites are presented in table 6 and were calculated from the discrete water-quality samples collected in each WY.

The annual 85th-percentile concentrations (table 5) for WYs 2011-2016 based on the R-LOADEST estimated daily loads ranged from $0.62 \mu \mathrm{g} / \mathrm{L}$ to $1.1 \mu \mathrm{g} / \mathrm{L}$ at Uncompahgre River at Colona to $12.1 \mu \mathrm{g} / \mathrm{L}$ to $18.7 \mu \mathrm{g} / \mathrm{L}$ at Uncompahgre River at Delta. The only core sites that exceeded the State of Colorado water-quality standard of $4.6 \mu \mathrm{g} / \mathrm{L}$ during WYs 2011-2016 were Uncompahgre River at Delta and Whitewater; however, Whitewater did not exceed the standard in WY 2015 or WY 2016.

The annual 85th-percentile concentrations based on the discrete samples in table 6 ranged from $0.16 \mu \mathrm{g} / \mathrm{L}$ and 0.17 $\mu \mathrm{g} / \mathrm{L}$ at Gunnison River below Gunnison Tunnel to $62.2 \mu \mathrm{g} / \mathrm{L}$ and $170 \mu \mathrm{g} / \mathrm{L}$ at Loutzenhizer Arroyo at North River Road. At Loutzenhizer Arroyo at North River Road, five out of six samples collected in WY 2015 had discharges greater than 50 cubic feet per second $\left(\mathrm{ft}^{3} / \mathrm{s}\right)$ and were collected during the irrigation season (April 1-October 31), when discharges are higher than normal due to irrigation return flows and concentrations can be lower due to dilution. This explains the low $(62.2 \mu \mathrm{g} / \mathrm{L})$ 85th-percentile concentration value in WY 2015.

The largest 85th-percentile concentrations for WYs 2011-2016 occurred at Loutzenhizer Arroyo at North River Road (table 6). Cedar Creek near Mouth, Loutzenhizer Arroyo at North River Road, Uncompahgre River at Delta, and Cummings Gulch at Mouth were the only sites to exceed the State of Colorado water-quality standard of $4.6 \mu \mathrm{g} / \mathrm{L}$ since WY 2014.

A sample collected on July 19, 2016, at Loutzenhizer Arroyo at North River Road had the lowest dissolved-selenium concentration ever measured at that site $(14.0 \mu \mathrm{g} / \mathrm{L})$. Low concentrations also were measured at Smith Fork near Lazear, North Fork Gunnison River near Lazear, Tongue Creek at Cory, Uncompahgre River at Colona, Cedar Creek near Mouth, Dry Creek at Mouth, Uncompahgre River at Delta, Cummings Gulch at Mouth, Roubideau Creek near Mouth, and Whitewater in WY 2015 and (or) WY 2016.

\section{Trend Analysis of Dissolved-Selenium Concentrations and Loads}

Using methods described in Mayo and Leib (2012), a trend analysis of dissolved-selenium concentrations and loads was completed using water-quality data collected at Whitewater. The calibration dataset contained all available discrete water-quality samples from WY 1986 to WY 2016. This process ensured that all data used by Mayo and Leib (2012) were included in the dataset used for model development through WY 2016. A second period from WY 1994 to WY 2016 is included and used the same methods as Mayo and Leib (2012) to provide emphasis on the more recently collected data.

A continuing downward trend in annual dissolvedselenium load was observed at Whitewater, as indicated in tables 7 and 8 . The dissolved-selenium loads decreased from 22,300 pounds (lb) in WY 1986 to 13,200 lb in WY 2016, a decrease of $9,100 \mathrm{lb}$ (table 7). This decrease represents a 40.8 percent reduction during the time period, and an additional 12.3 percent reduction from the 28.6 percent reduction reported through WY 2008 in Mayo and Leib (2012). As shown in table 7, the dissolved-selenium load 95-percent confidence levels for WY 1986 were 19,900 lb (lower) and 24,800 lb (upper); for WY 2016, the dissolved-selenium load 95-percent confidence levels were 12,200 lb (lower) and 14,200 lb (upper). For WY 1994 to WY 2016 (table 8), the annual dissolved-selenium load decreased from 18,900 lb in 1994 to $12,600 \mathrm{lb}$ in 2016, a decrease of $6,300 \mathrm{lb}$, or 33.3 percent.

The time component was removed from the R-LOADEST regression model to graphically demonstrate the trend in dissolved-selenium concentration so that concentrations were only adjusted for flow (Mayo and Leib, 2012). The calibration dataset was then used to predict dissolved-selenium concentrations for each water sample and a residual was computed by subtracting the predicted concentrations from the measured concentration. The resulting residuals are plotted by year with a Locally Weighted Scatterplot Smoothing (LOWESS) fit line in figure 4 for WYs 1986-2016 and in figure 5 for WYs 1994-2016. Both figures 4 and 5 confirm a continuing decrease in dissolved selenium concentration during the trend periods.

\section{Summary}

The Gunnison Basin Selenium Management Program implemented a water-quality monitoring network in 2011 in the lower Gunnison River Basin in Colorado. Selenium is a trace element that bioaccumulates in aquatic food chains and can cause reproductive failure, deformities, and other harmful effects. This report presents the percentile values of selenium because regulatory agencies in Colorado make decisions based on the U.S. Environmental Protection Agency (EPA) 
Table 5. Estimated dissolved-selenium 85th-percentile concentration, in micrograms per liter, from daily dissolved-selenium loads calculated using multiple linear regression techniques in R-LOADEST (Runkel and others, 2004), at five core sites with U.S. Geological Survey streamflow-gaging stations for water years 2011-2016.

[USGS, U.S. Geological Survey; WY, water year, defined as the 12-month period from October 1 through September 30 and designated by the year in which it ends; $\mu \mathrm{g} / \mathrm{L}$, microgram per liter]

\begin{tabular}{|c|c|c|c|c|c|c|c|c|c|}
\hline \multirow{2}{*}{$\begin{array}{c}\text { Map index } \\
\text { number } \\
\text { (fig. 1) }\end{array}$} & \multirow{2}{*}{$\begin{array}{c}\text { USGS } \\
\text { station } \\
\text { number }\end{array}$} & \multirow{2}{*}{ USGS station short name } & \multicolumn{6}{|c|}{$\begin{array}{l}\text { 85th-percentile concentrations for } \\
\text { dissolved selenium ( } \mu \mathrm{g} / \mathrm{l})\end{array}$} & \multirow{2}{*}{$\begin{array}{l}\text { Difference in dissolved- } \\
\text { selenium concentration, } \\
\text { between WY } 2011 \text { and } \\
\text { WY } 2016(\mu \mathrm{g} / \mathrm{L})\end{array}$} \\
\hline & & & $\begin{array}{l}\text { WY } \\
2011^{1}\end{array}$ & $\begin{array}{c}\text { WY } \\
2012^{1}\end{array}$ & $\begin{array}{l}\text { WY } \\
2013^{1}\end{array}$ & $\begin{array}{l}\text { WY } \\
2014^{1}\end{array}$ & $\begin{array}{l}\text { WY } \\
2015\end{array}$ & $\begin{array}{l}\text { WY } \\
2016\end{array}$ & \\
\hline 3 & 09136100 & North Fork Gunnison River near Lazear & 3.4 & 4.1 & 3.8 & 2.6 & 2.5 & 2.3 & -1.1 \\
\hline 8 & 09144250 & Gunnison River at Delta & 3.0 & 3.8 & 3.7 & 3.0 & 2.4 & 2.3 & -0.7 \\
\hline 13 & 09149500 & Uncompahgre River at Delta & 18.7 & 15.4 & 15.3 & 16.7 & 14.9 & 12.1 & -6.6 \\
\hline 18 & 09152500 & Whitewater & 6.6 & 6.4 & 7.1 & 6.2 & 4.2 & 3.6 & -3.0 \\
\hline
\end{tabular}

${ }^{1}$ Values from Henneberg, 2016.

Table 6. Dissolved-selenium 85th-percentile concentrations for 5 core sites with U.S. Geological Survey streamflow-gaging stations and 13 ancillary sites, in micrograms per liter, for discrete water-quality samples collected during water years 2011-2016.

[USGS, U.S. Geological Survey; WY, water year, defined as the 12-month period from October 1 through September 30 and designated by the year in which it ends; - , insufficient data to calculate a concentration; $\mu \mathrm{g} / \mathrm{L}$, microgram per liter]

\begin{tabular}{|c|c|c|c|c|c|c|c|c|}
\hline \multirow{2}{*}{$\begin{array}{c}\text { Map } \\
\text { index } \\
\text { number } \\
\text { (fig. 1) }\end{array}$} & \multirow[b]{2}{*}{ USGS station number } & \multirow[b]{2}{*}{ USGS station short name } & \multicolumn{6}{|c|}{ 85th percentile concentrations ( $\mu \mathrm{g} / \mathrm{L}$ ) } \\
\hline & & & $\begin{array}{c}\text { WY } \\
2011^{1}\end{array}$ & $\begin{array}{c}\text { WY } \\
2012^{1}\end{array}$ & $\begin{array}{c}\text { WY } \\
2013^{1}\end{array}$ & $\begin{array}{c}\text { WY } \\
2014^{1}\end{array}$ & $\begin{array}{l}\text { WY } \\
2015\end{array}$ & $\begin{array}{l}\text { WY } \\
2016\end{array}$ \\
\hline 1 & 09128000 & Gunnison River below Gunnison Tunnel & 0.17 & 0.16 & - & - & - & - \\
\hline 2 & 09129600 & Smith Fork near Lazear & - & 2.0 & 2.3 & 1.6 & 2.0 & 1.8 \\
\hline 5 & 09144200 & Tongue Creek at Cory & 3.5 & 10.0 & 9.3 & 6.0 & 3.3 & 4.4 \\
\hline 6 & 09137500 & Gunnison River near Cory & 2.2 & 2.0 & 3.8 & 2.6 & 1.8 & 1.4 \\
\hline 7 & 384617108022901 & Gunnison River near Hartland Dam & 2.4 & 2.2 & 4.4 & 2.5 & 2.5 & - \\
\hline 8 & 09144250 & Gunnison River at Delta & 2.9 & 3.8 & 3.5 & 2.6 & 2.7 & 2.0 \\
\hline 12 & 384202108032001 & Dry Creek at mouth near Delta & - & - & - & 3.8 & 3.5 & 3.5 \\
\hline 13 & 09149500 & Uncompahgre River at Delta & 12.5 & 13.4 & 16.0 & 14.8 & 9.6 & 11.0 \\
\hline 14 & 384448108070301 & Cummings Gulch at Mouth & - & - & - & 11.4 & 6.7 & 8.6 \\
\hline 15 & 09150500 & Roubideau Creek near Mouth & - & 2.5 & 2.8 & 2.6 & 2.0 & 2.2 \\
\hline 16 & 384527108152701 & Gunnison River above Escalante Creek & - & 5.8 & 8.1 & 6.3 & 4.4 & 3.6 \\
\hline 17 & 385011108225401 & Gunnison River below Dominguez Creek & - & - & 5.9 & 6.0 & 4.0 & 3.8 \\
\hline 18 & 09152500 & Whitewater & 4.2 & 6.3 & 6.9 & 6.4 & 4.0 & 3.9 \\
\hline
\end{tabular}

${ }^{1}$ Values from Henneberg, 2016.

${ }^{2}$ Five of six samples obtained in WY 2015 were during the irrigation season (April-October), when concentrations are typically lower. 
Table 7. Annual dissolved-selenium trend from water year 1986 to water year 2016 at U.S. Geological Survey streamflow-gaging station 09152500, Whitewater.

[Water year defined as the 12-month period from October 1 through September 30 and designated by the year in which it ends. \%, percent; - , not applicable; $\mathrm{ft}^{3} / \mathrm{s}$, cubic foot per second; $\mathrm{lb}$, pound; $\mu \mathrm{g} / \mathrm{L}$, microgram per liter]

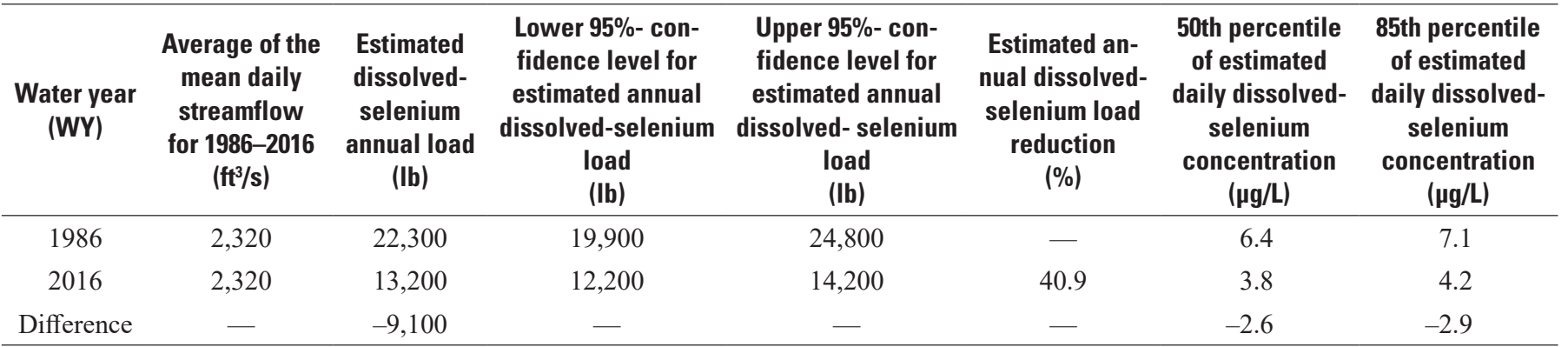

Table 8. Annual dissolved-selenium trend from water year 1994 to water year 2016 at U.S. Geological Survey streamflow-gaging station 09152500, Whitewater.

[Water year defined as the 12-month period from October 1 through September 30 and designated by the year in which it ends. \%, percent; - , not applicable; $\mathrm{ft}^{3} / \mathrm{s}$, cubic foot per second; $\mathrm{lb}$, pound; $\mu \mathrm{g} / \mathrm{L}$, microgram per liter]

\begin{tabular}{|c|c|c|c|c|c|c|c|}
\hline $\begin{array}{l}\text { Water year } \\
\text { (WY) }\end{array}$ & $\begin{array}{l}\text { Average of the } \\
\text { mean daily } \\
\text { streamflow for } \\
1994 \text { to } 2016 \\
\left(\mathrm{ft}^{3} / \mathrm{s}\right)\end{array}$ & $\begin{array}{l}\text { Estimated } \\
\text { dissolved- } \\
\text { selenium } \\
\text { annual load } \\
\text { (Ib) }\end{array}$ & $\begin{array}{l}\text { Lower } 95 \% \text { - con- } \\
\text { fidence level for } \\
\text { estimated annual } \\
\text { dissolved-seleni- } \\
\text { um load } \\
\text { (lb) }\end{array}$ & $\begin{array}{l}\text { Upper } 95 \% \text { - con- } \\
\text { fidence level for } \\
\text { estimated annual } \\
\text { dissolved-seleni- } \\
\text { um load } \\
\text { (lb) }\end{array}$ & $\begin{array}{l}\text { Estimated an- } \\
\text { nual dissolved- } \\
\text { selenium load } \\
\text { reduction } \\
(\%)\end{array}$ & $\begin{array}{l}\text { 50th percentile } \\
\text { of estimated } \\
\text { daily dissolved- } \\
\text { selenium } \\
\text { concentration } \\
(\mu \mathrm{g} / \mathrm{L})\end{array}$ & $\begin{array}{l}\text { 85th percentile } \\
\text { of estimated } \\
\text { daily dissolved- } \\
\text { selenium } \\
\text { concentration } \\
(\mu \mathrm{g} / \mathrm{L})\end{array}$ \\
\hline 1994 & 2,280 & 18,900 & 17,200 & 20,800 & - & 5.5 & 6.1 \\
\hline
\end{tabular}

Clean Water Act Section 303(d) that uses percentile values of concentration. Also presented are dissolved-selenium loads at 18 sites in the lower Gunnison River Basin for water years (WYs) 2011-2016 (October 1, 2010, through September 30, 2016). Annual dissolved-selenium loads were calculated for five sites with continuous U.S. Geological Survey (USGS) streamflow-gaging stations. Annual dissolved-selenium loads for WY 2011 through WY 2016 ranged from 179 and 391 pounds (lb) at Uncompahgre River at Colona to 11,100 and 17,300 $\mathrm{lb}$ at Gunnison River near Grand Junction, respectively.

Instantaneous loads were calculated for 5 sites with continuous U.S. Geological Survey (USGS) streamflow-gaging stations and 13 ancillary sites where discrete water-quality sampling also took place, using discrete water-quality samples and the associated discharge measurements collected during the period. Median instantaneous loads ranged from 0.01 pound per day (lb/d) at Smith Fork near Lazear to $33.0 \mathrm{lb} / \mathrm{d}$ at Whitewater. Mean instantaneous loads ranged from 0.06 $\mathrm{lb} / \mathrm{d}$ at Smith Fork near Lazear to $36.2 \mathrm{lb} / \mathrm{d}$ at Whitewater. Most tributary sites in the basin had a median instantaneous dissolved-selenium load of less than $20.0 \mathrm{lb} / \mathrm{d}$. In general, dissolved-selenium loads at Gunnison River main-stem sites showed an increase from upstream to downstream.
The State of Colorado water-quality standard for dissolved selenium of 4.6 micrograms per liter $(\mu \mathrm{g} / \mathrm{L})$ was compared to the 85 th percentiles for dissolved selenium at selected sites. Annual 85th percentiles for dissolved selenium were calculated for the five core sites having USGS streamflow-gaging stations using estimated dissolved-selenium concentrations from linear regression models. The 85th-percentile concentrations for WYs 2011-2016 based on this method ranged from $0.62 \mu \mathrm{g} / \mathrm{L}$ and $1.1 \mu \mathrm{g} / \mathrm{L}$ at Uncompahgre River at Colona to $12.1 \mu \mathrm{g} / \mathrm{L}$ and $18.7 \mu \mathrm{g} / \mathrm{L}$ at Uncompahgre River at Delta.

The 85 th percentiles for dissolved selenium also were calculated for sites with sufficient data using water-quality samples collected during WYs 2011-2016. The annual 85 th-percentile concentrations based on the discrete samples ranged from $0.16 \mu \mathrm{g} / \mathrm{L}$ and $0.17 \mu \mathrm{g} / \mathrm{L}$ at Gunnison River below Gunnison Tunnel to $62.2 \mu \mathrm{g} / \mathrm{L}$ and $170 \mu \mathrm{g} / \mathrm{L}$ at Loutzenhizer Arroyo at North River Road.

A trend analysis was completed for Whitewater to determine if dissolved-selenium loads are increasing or decreasing. The trend analysis indicates a decrease of 9,100 lb from WY 1986 to WY 2016, a 40.8 percent reduction during the time period. The trend analysis for the annual dissolvedselenium load for WY 1994 to WY 2016 indicates a decrease of $6,300 \mathrm{lb}$ per year, or 33.3 percent. 


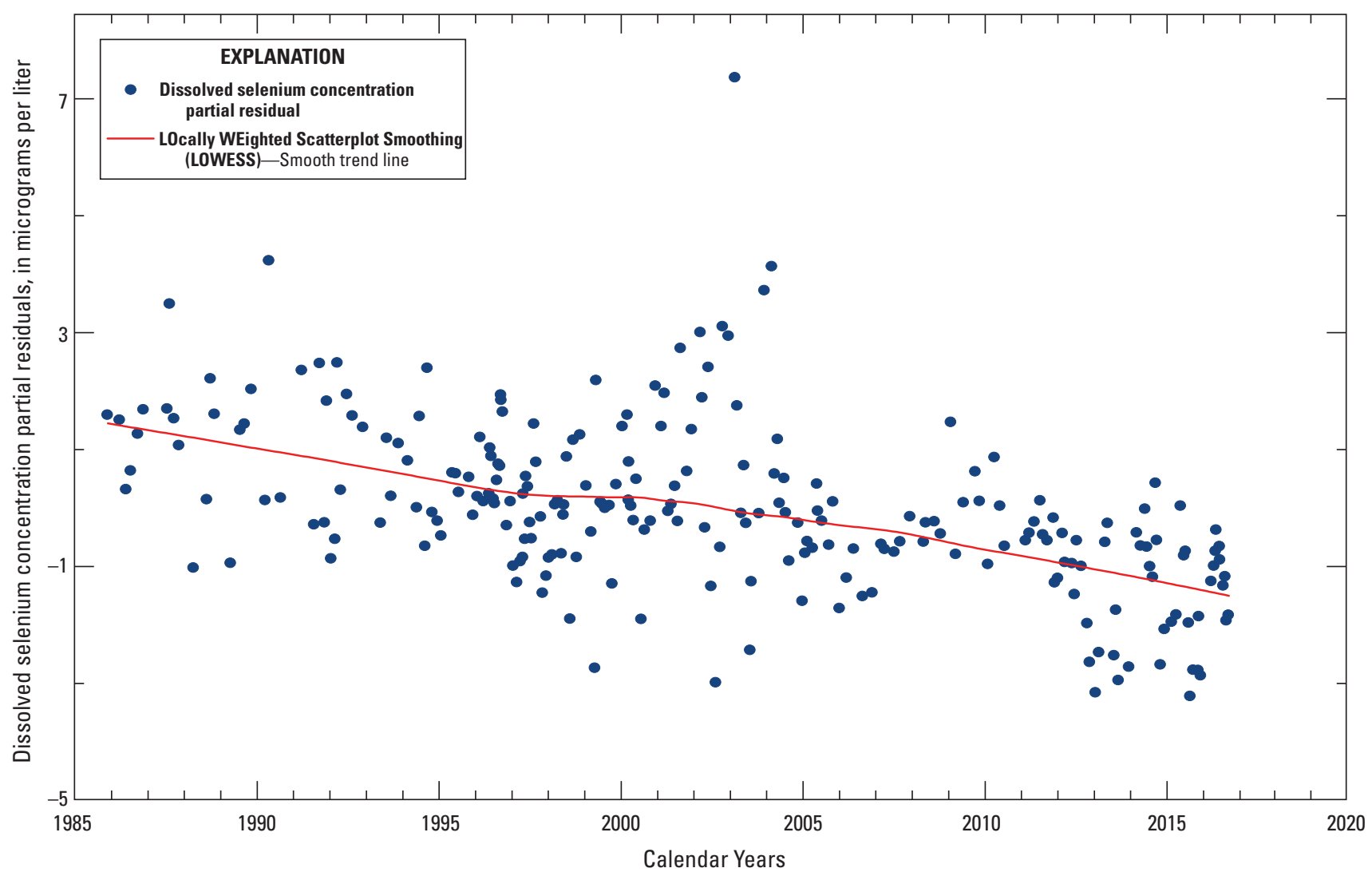

Figure 4. Plot of dissolved-selenium concentration partial residuals and Locally Weighted Scatterplot Smoothing (LOWESS) fit line for Whitewater (09152500) for water years 1986-2016.

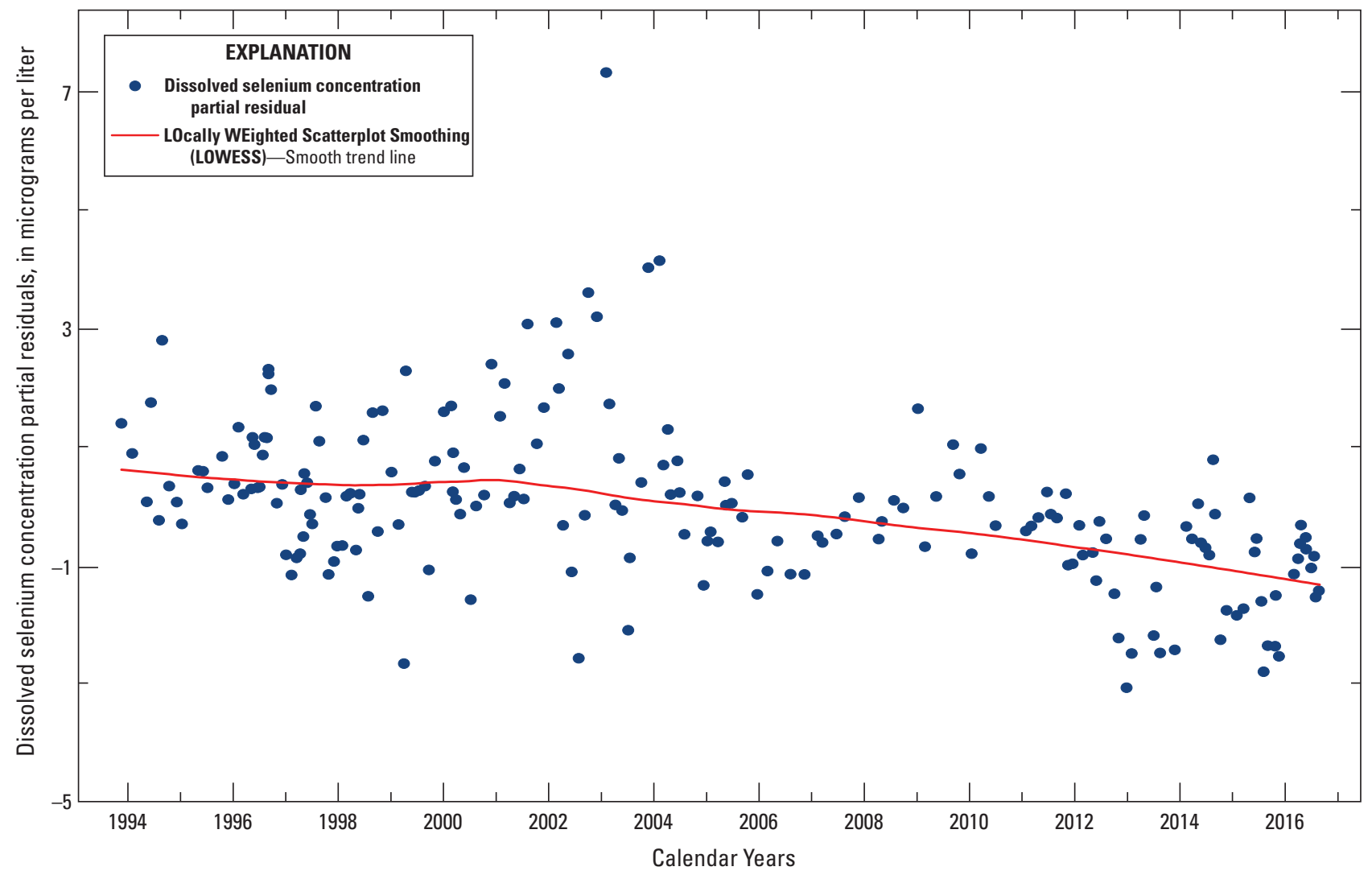

Figure 5. Plot of dissolved-selenium concentration partial residuals and Locally Weighted Scatterplot Smoothing (LOWESS) fit line for Whitewater (09152500) for water years 1994-2016. 


\section{References Cited}

Bureau of Reclamation, 2011, Selenium Management Program-Program formulation document, Gunnison River Basin, Colorado: U.S. Bureau of Reclamation, Selenium Management Program Workgroup, 80 p., accessed February 12, 2012, at http://www.usbr.gov/uc/wcao/progact/smp/ docs.html.

Butler, D.L., 1996, Trend analysis of selected water-quality data associated with salinity control projects in the Grand Valley, in the lower Gunnison Basin, and at Meeker Dome, western Colorado: U.S. Geological Survey Water-Resources Investigations Report 95-4274, 38 p. [Also available at https://pubs.er.usgs.gov/publication/wri954274.]

Cohn, T.A., Delong, L.L., Gilroy, E.J., Hirsh, R.M., and Wells, D.K., 1989, Estimating constituent loads: Water Resources Research, v. 25, no. 5, p. 937-942.

Hamilton, S.J., 1998, Selenium effects on endangered fish in the Colorado River Basin, in Frankenberger, W.T., Jr., and Engberg, R.A., eds., Environmental chemistry of selenium: New York, Marcel Dekker, p. 297-314.

Henneberg, M.F., 2016, 2014 annual summary of the lower Gunnison River Basin Selenium Management Program water-quality monitoring, Colorado: U.S. Geological Survey Open-File Report 2016-1129, 25 p., https://doi. org/10.3133/ofr20161129.

Kircher, J.E., Dinicola, R.S., and Middelburg, R.M., 1984, Trend analysis of salt load and evaluation of the frequency of water-quality measurements for the Gunnison, the Colorado, and the Dolores Rivers in Colorado and Utah: U.S. Geological Survey Water-Resources Investigations Report 84-4048, 69 p. [Also available at https://pubs.er.usgs.gov/ publication/wri844048.]
Lemly, A.D., 2002, Selenium assessment in aquatic ecosystems - A guide for hazard evaluation and water quality criteria: New York, Springer-Verlag, $162 \mathrm{p}$.

Mayo, J.W., and Leib, K.J., 2012, Flow-adjusted trends in dissolved selenium load and concentration in the Gunnison and Colorado Rivers near Grand Junction, Colorado, water years 1986-2008: U.S. Geological Survey Scientific Investigations Report 2012-5088, 33 p. [Also available at https://pubs.er.usgs.gov/publication/sir20125088.]

Richards, R.J., and Leib, K.J., 2011, Characterization of hydrology and salinity in the Dolores project area, McElmo Creek Region, southwest Colorado, 1978-2006: U.S. Geological Survey Scientific Investigations Report 2010-5218, 38 p. [Also available at https://pubs.er.usgs. gov/publication/sir20105218.]

Runkel, R.L., Crawford, C.G., and Cohn, T.A., 2004, Load estimator (LOADEST) - A FORTRAN program for estimating constituent loads in streams and rivers: U.S. Geological Survey Techniques and Methods, book 4, chap. A5, 69 p. [Also available at https://pubs.usgs.gov/ $\mathrm{tm} / 2005 / \mathrm{tm} 4 \mathrm{~A} 5 /$.

Sprague, L.A., Clark, M.L., Rus, D.L., Zelt, R.B., Flynn, J.L., and Davis, J.V., 2006, Nutrient and suspendedsediment trends in the Missouri River Basin, 1993-2003: U.S. Geological Survey Scientific Investigations Report 2006-5231, 80 p. [Also available at https://pubs.usgs.gov/ sir/2006/5231/.]

U.S. Fish and Wildlife Service, 2009, Final Gunnison River Basin programmatic biological opinion: U.S. Fish and Wildlife Service, 123 p., accessed January 4, 2012, at http:// www.usbr.gov/uc/wcao/rm/aspeis/pdfs/aspinallpbo_final.pdf.

U.S. Geological Survey, 2016, National Water Information System: U.S. Geological Survey database, accessed May 01, 2017, at https://doi.org/10.5066/F7P55KJN.

Publishing support provided by the Science Publishing Network, Denver Publishing Service Center

For more information concerning the research in this report, contact the Center Director, USGS Geology, Geophysics, and Geochemistry Science Center

Box 25046, Mail Stop 973

Denver, CO 80225

(303) 236-1800

Or visit Geology, Geophysics, and Geochemistry Science Center website at

https://minerals.cr.usgs.gov/

This publication is available online at

https://doi.org/10.3133/sir20185001 


\section{Appendix 1. R-LOADEST Equation Forms, Variable Coefficients, and Statistical Diagnostics}

A summary of the equation forms used to estimate annual dissolved-selenium load at the five core sites in the lower Gunnison River Basin for water year 2015 is presented in table 1.1 and water year 2016 in table 1.2. Tables 1.3 and 1.4 provide regression model coefficients and statistical diagnostics for the five core sites for water years 2015 and 2016, respectively.

Table 1.1. Summary of equation forms used to estimate annual dissolved-selenium load for water year 2015 at five core sites with U.S. Geological Survey streamflow-gaging stations in the lower Gunnison River Basin.

[USGS, U.S. Geological Survey; ln, natural logarithm; load, dissolved-selenium load in pounds per day (lb/d); $\beta 0$, intercept of the regression on the y-axis; $\beta 1-\beta 5$, regression coefficients; Q, centered daily streamflow in cubic feet per second ( $\left.\mathrm{ft}^{3} / \mathrm{s}\right)$; $\sin (2 \pi$ dectime $)$, sine function of a Fourier Series; $\pi$, approximately 3.141593; dectime, centered decimal time in decimal years; $\cos (2 \pi$ dectime $)$, cosine function of a Fourier Series; $\varepsilon$, remaining unexplained variability in the data (error); SC, daily mean specific conductance in microsiemens per centimeter at 25 degrees Celsius $\left(\mu \mathrm{S} / \mathrm{cm}\right.$ at $\left.\left.25^{\circ} \mathrm{C}\right)\right]$

\begin{tabular}{ll}
$\begin{array}{c}\text { USGS station } \\
\text { number }\end{array}$ & \multicolumn{1}{c}{ Equation form $^{1}$} \\
\hline 09136100 & $\ln ($ load $)=\beta_{0}+\beta_{1} \ln (\mathrm{Q})+\beta_{2} \sin (2 \pi$ dectime $)+\beta_{3} \cos (2 \pi$ dectime $)+\varepsilon$ \\
09144250 & $\ln ($ load $)=\beta_{0}+\beta_{1} \ln (\mathrm{Q})+\beta_{2} \sin (2 \pi$ dectime $)+\beta_{3} \cos (2 \pi$ dectime $)+\varepsilon$ \\
$09147500^{2}$ & $\ln ($ load $)=\beta_{0}+\beta_{1} \ln (\mathrm{Q})+\beta_{2} \mathrm{SC}+\varepsilon$ \\
$09147500^{3}$ & $\ln ($ load $)=\beta_{0}+\beta_{1} \ln (\mathrm{Q})+\beta_{2} \sin (2 \pi$ dectime $)+\beta_{3} \cos (2 \pi$ dectime $)+\varepsilon$ \\
09149500 & $\ln ($ load $)=\beta_{0}+\beta_{1} \ln (\mathrm{Q})+\beta_{2} \sin (2 \pi$ dectime $)+\beta_{3} \cos (2 \pi$ dectime $)+\varepsilon$ \\
$09152500^{2}$ & $\ln ($ load $)=\beta_{0}+\beta_{1} \ln (\mathrm{Q})+\beta_{2} \mathrm{SC}+\varepsilon$ \\
$09152500^{3}$ & $\ln ($ load $)=\beta_{0}+\beta_{1} \ln (\mathrm{Q})+\beta_{2} \ln (\mathrm{Q})^{2}+\beta_{3}$ dectime $+\beta_{4} \sin (2 \pi$ dectime $)+\beta_{5} \cos (2 \pi$ dectime $)+\varepsilon$ \\
\hline
\end{tabular}

${ }^{1}$ Any bias that is introduced by the log transformation needs to be corrected if the results are transformed out of log space (Cohn and others, 1989), but this correction is automatically applied by the statistical software used for the regression analysis (Mayo and Leib, 2012).

${ }^{2}$ Equation form used when specific conductance data were available.

${ }^{3}$ Equation form used when specific conductance data were absent.

Table 1.2. Summary of equation forms used to estimate annual dissolved-selenium load for water year 2016 at five core sites with U.S. Geological Survey streamflow-gaging stations in the lower Gunnison River Basin.

[USGS, U.S. Geological Survey; ln, natural logarithm; load, dissolved-selenium load in pounds per day (lb/d); $\beta_{0}$, intercept of the regression on the $y$-axis; $\beta_{1}-\beta_{5}$, regression coefficients; $\mathrm{Q}$, centered daily streamflow in cubic feet per second $(\mathrm{ft} 3 / \mathrm{s})$; $\sin (2 \pi$ dectime), sine function of a Fourier Series; $\pi$, approximately 3.141593; dectime, centered decimal time in decimal years; $\cos (2 \pi$ dectime $)$, cosine function of a Fourier Series; $\varepsilon$, remaining unexplained variability in the data (error); SC, daily mean specific conductance in microsiemens per centimeter at 25 degrees Celsius $\left(\mu \mathrm{S} / \mathrm{cm}\right.$ at $\left.\left.25^{\circ} \mathrm{C}\right)\right]$

\begin{tabular}{ll}
\hline $\begin{array}{c}\text { USGS station } \\
\text { number }\end{array}$ & \multicolumn{1}{c}{ Equation form $^{1}$} \\
\hline 09136100 & $\ln ($ load $)=\beta_{0}+\beta_{1} \ln (\mathrm{Q})+\beta_{2}$ dectime $+\beta_{3} \sin (2 \pi$ dectime $)+\beta_{4} \cos (2 \pi$ dectime $)+\varepsilon$ \\
09144250 & $\ln ($ load $)=\beta_{0}+\beta_{1} \ln (\mathrm{Q})+\beta_{2} \sin (2 \pi$ dectime $)+\beta_{3} \cos (2 \pi$ dectime $)+\varepsilon$ \\
09147500 & $\ln ($ load $)=\beta_{0}+\beta_{1} \ln (Q)+\varepsilon$ \\
09149500 & $\ln ($ load $)=\beta_{0}+\beta_{1} \ln (Q)+\beta_{2} \sin (2 \pi$ dectime $)+\beta_{3} \cos (2 \pi$ dectime $)+\varepsilon$ \\
09152500 & $\ln ($ load $)=\beta_{0}+\beta_{1} \ln (Q)+\beta_{2} \mathrm{SC}+\varepsilon$ \\
$09152500^{2}$ & $\ln ($ load $)=\beta_{0}+\beta_{1} \ln (Q)+\beta_{2} \ln (Q)^{2}+\beta_{3}$ dectime $+\beta_{4}(\text { dectime })^{2}+\beta_{5} \sin (2 \pi$ dectime $)+\beta_{6} \cos (2 \pi$ dectime $)+\varepsilon$ \\
$09152500^{3}$ & $\ln ($ load $)=\beta_{0}+\beta_{1} \ln (Q)+\beta_{2} \ln (Q)^{2}+\beta_{3}$ dectime $+\beta_{4}(\text { dectime })^{2}+\beta_{5} \sin (2 \pi$ dectime $)+\beta_{6} \cos (2 \pi$ dectime $)+\varepsilon$ \\
\hline
\end{tabular}

${ }^{1}$ Any bias that is introduced by the log transformation needs to be corrected if the results are transformed out of log space (Cohn and others, 1989), but this correction is automatically applied by the statistical software used for the regression analysis (Mayo and Leib, 2012).

${ }^{2}$ Equation form used for 1986-2016 trend analysis.

${ }^{3}$ Equation form used for 1994-2016 trend analysis. 
Table 1.3. Regression model coefficients and statistical diagnostics at five core sites with U.S. Geological Survey streamflow-gaging stations in the lower Gunnison River, water year 2015.

[USGS, U.S. Geological Survey; ln, natural logarithm; Q, centered daily streamflow in cubic feet per second ( $\left.\mathrm{ft}^{3} / \mathrm{s}\right)$; dectime, centered decimal time in decimal years; $\sin (2 \pi$ dectime), sine function of a Fourier Series; $\pi$, approximately $3.141593 ; \cos (2 \pi$ dectime $)$, cosine function of a Fourier Series; SC, daily mean specific conductance in microsiemens per centimeter at 25 degrees Celsius $\left(\mu \mathrm{S} / \mathrm{cm}\right.$ at $\left.25^{\circ} \mathrm{C}\right)$; ERV, estimated residual variance; $\mathrm{R}^{2}$, coefficient of determination; SCR, serial correlation of the residuals; - , no coefficient available]

\begin{tabular}{|c|c|c|c|c|c|c|c|c|c|c|c|}
\hline $\begin{array}{c}\text { USGS station } \\
\text { Number }\end{array}$ & $\begin{array}{c}\text { Y-axis } \\
\text { Intercept }\end{array}$ & $\ln (0)$ & $\ln (0) 2$ & $1 / 0$ & dectime & $\sin (2 \pi$ dectime $)$ & $\cos (2 \pi$ dectime $)$ & SC & ERV & $\mathbf{R}^{2}$ & SCR \\
\hline 09136100 & 1.386 & 0.569 & - & - & - & -0.137 & -0.079 & - & 0.003 & 99.46 & 0.598 \\
\hline $09147500^{1}$ & -11.56 & 1.441 & - & - & - & - & - & 0.007 & 0.043 & 95.85 & -0.763 \\
\hline $09147500^{2}$ & -0.483 & 1.071 & - & - & - & 0.373 & 0.178 & - & 0.071 & 94.47 & -0.668 \\
\hline $09152500^{2}$ & 3.807 & 0.389 & -0.221 & - & -0.263 & -0.145 & 0.020 & - & 0.032 & 78.52 & -0.292 \\
\hline
\end{tabular}

${ }^{1}$ Coefficients and diagnostics when specific conductance data were available.

${ }^{2}$ Coefficients and diagnostics when specific conductance data were absent.

Table 1.4. Regression model coefficients and statistical diagnostics at five core sites with U.S. Geological Survey streamflow-gaging stations in the lower Gunnison River Basin, water year 2016.

[USGS, U.S. Geological Survey; ln, natural logarithm; Q, centered daily streamflow in cubic feet per second ( $\left.\mathrm{ft}^{3} / \mathrm{s}\right)$; dectime, centered decimal time in decimal years; $\sin (2 \pi$ dectime $)$, sine function of a Fourier Series; $\pi$, approximately 3.141593 ; $\cos (2 \pi$ dectime $)$, cosine function of a Fourier Series; SC, daily mean specific conductance in microsiemens per centimeter at 25 degrees Celsius $\left(\mu \mathrm{S} / \mathrm{cm}\right.$ at $\left.25^{\circ} \mathrm{C}\right)$; ERV, estimated residual variance; $\mathrm{R}^{2}$, coefficient of determination; SCR, serial correlation of the residuals; --, no coefficient available]

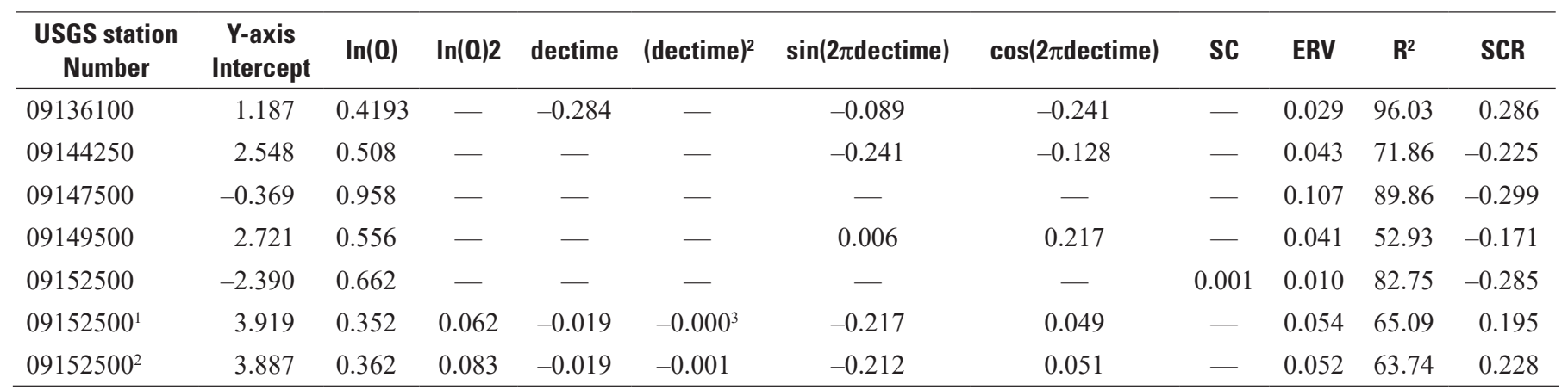

${ }^{1}$ Coefficients and diagnostics for 1986-2016 trend analysis.

${ }^{2}$ Coefficients and diagnostics for 1994-2016 trend analysis.

${ }^{3}$ Coefficient reported in R-LOADEST was -0.0004 , reported to 3 significant figures in table 1.4. 


\section{Appendix 2. Calibration Data For 2015 and 2016 Annual Load and Trend Regressions}

Table 2.1 provides calibration data for annual load regression models at selected sites. Calibration data for dissolvedselenium trend analysis at the U. S. Geological Survey streamflow-gaging station Gunnison River near Grand Junction (Whitewater) are presented in table 2.2.

Table 2.1. Calibration data for annual load regression models at selected U.S. Geological Survey streamflow-gaging stations.

$\left[\mathrm{ft}^{3} / \mathrm{s}\right.$, cubic foot per second; daily mean specific conductance in microsiemens per centimeter at 25 degrees Celsius $\left(\mu \mathrm{S} / \mathrm{cm}\right.$ at $\left.25^{\circ} \mathrm{C}\right) ; \mu \mathrm{g} / \mathrm{L}$, microgram per liter]

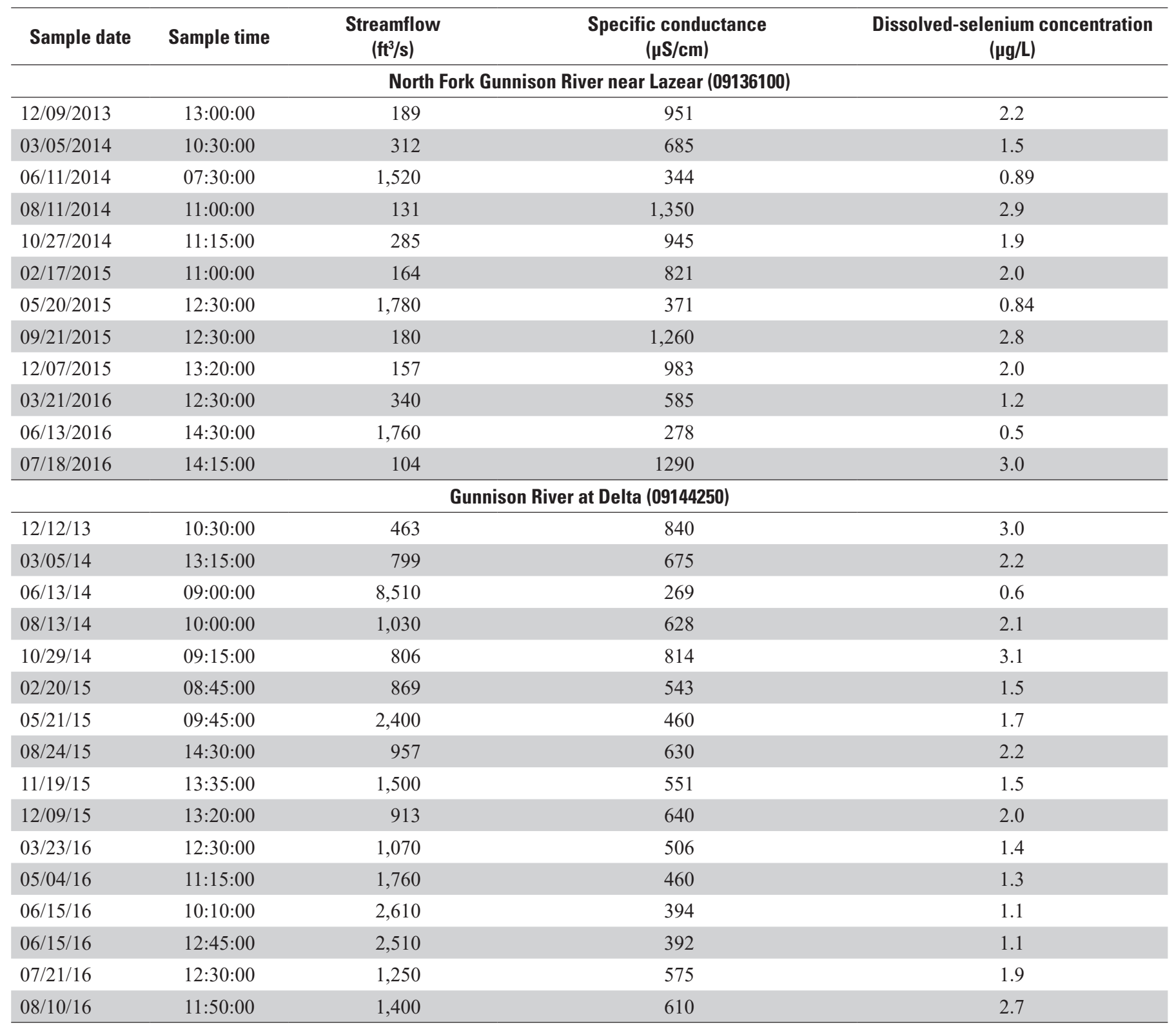


Table 2.1. Calibration data for annual load regression models at selected U.S. Geological Survey streamflow-gaging stations.-Continued [ft³ $/ \mathrm{s}$, cubic foot per second; daily mean specific conductance in microsiemens per centimeter at 25 degrees Celsius $\left(\mu \mathrm{S} / \mathrm{cm}\right.$ at $\left.25^{\circ} \mathrm{C}\right) ; \mu \mathrm{g} / \mathrm{L}$, microgram per liter]

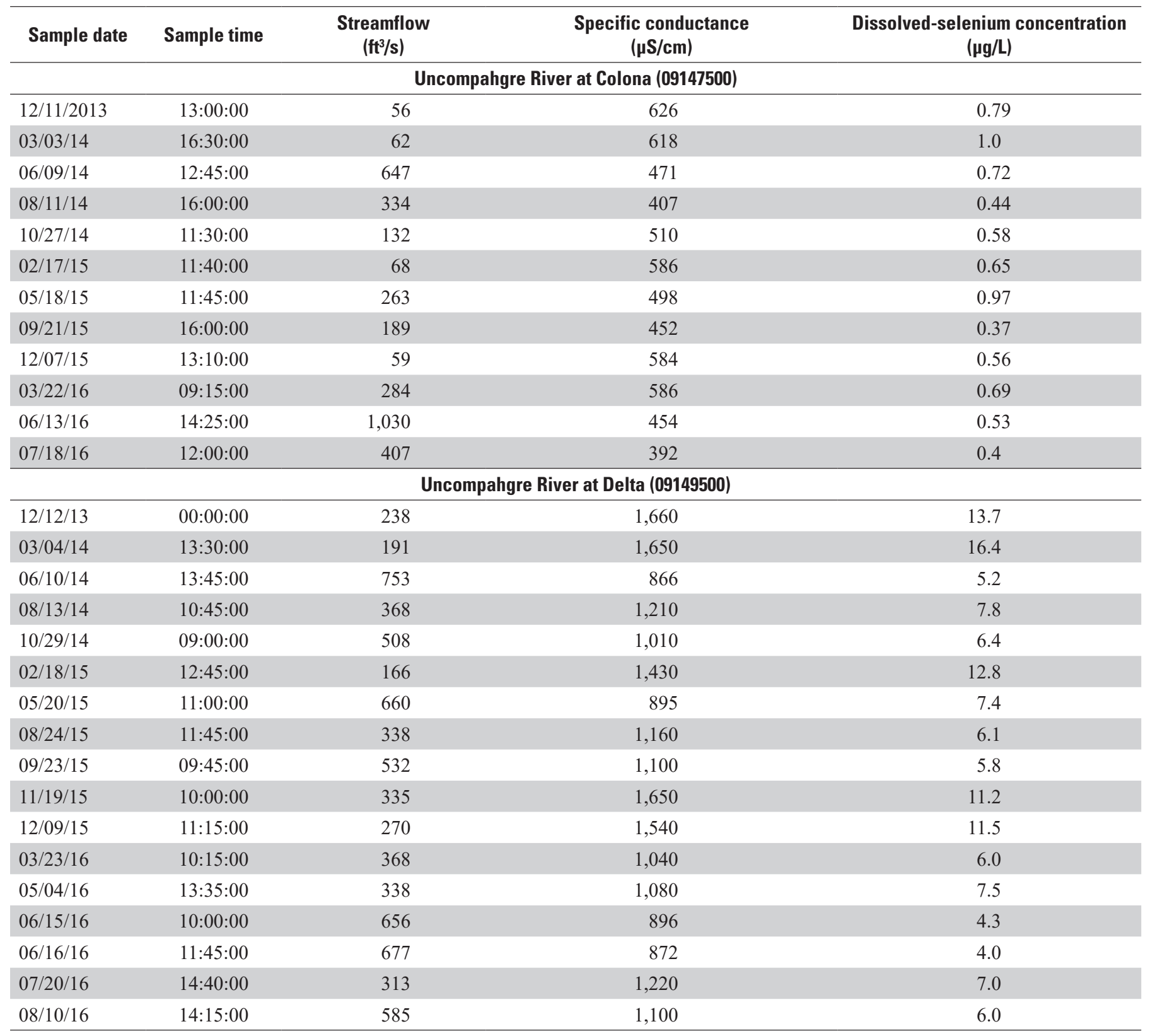


Table 2.1. Calibration data for annual load regression models at selected U.S. Geological Survey streamflow-gaging stations.-Continued $\left[\mathrm{ft} / \mathrm{s}\right.$, cubic foot per second; daily mean specific conductance in microsiemens per centimeter at 25 degrees Celsius $\left(\mu \mathrm{S} / \mathrm{cm}\right.$ at $\left.25^{\circ} \mathrm{C}\right) ; \mu \mathrm{g} / \mathrm{L}$, microgram per liter]

\begin{tabular}{|c|c|c|c|c|}
\hline Sample date & Sample time & $\begin{array}{l}\text { Streamflow } \\
\left(\mathrm{ft}^{3} / \mathrm{s}\right)\end{array}$ & $\begin{array}{l}\text { Specific conductance } \\
(\mu \mathrm{S} / \mathrm{cm})\end{array}$ & $\begin{array}{c}\text { Dissolved-selenium concentration } \\
(\mu \mathrm{g} / \mathrm{L})\end{array}$ \\
\hline \multicolumn{5}{|c|}{ Gunnison River near Grand Junction (Whitewater) (09152500) } \\
\hline $03 / 07 / 14$ & $13: 15: 00$ & 968 & 929 & 5.6 \\
\hline $04 / 15 / 14$ & 12:00:00 & 2,540 & 497 & 2.3 \\
\hline $07 / 18 / 14$ & 09:00:00 & 1,470 & 855 & 4.3 \\
\hline $08 / 14 / 14$ & 12:30:00 & 1,790 & 857 & 4.0 \\
\hline $09 / 10 / 14$ & $12: 45: 00$ & 2,330 & 1,030 & 5.2 \\
\hline $09 / 23 / 14$ & 10:30:00 & 1,820 & 1,020 & 5.2 \\
\hline $04 / 08 / 15$ & $14: 30: 00$ & 1,210 & 618 & 3.0 \\
\hline $05 / 21 / 15$ & $13: 30: 00$ & 3,400 & 576 & 2.6 \\
\hline $06 / 24 / 15$ & 09:45:00 & 9,140 & 316 & 0.9 \\
\hline $07 / 08 / 15$ & 09:30:00 & 2,990 & 625 & 2.5 \\
\hline $08 / 10 / 15$ & 09:15:00 & 1,570 & 884 & 3.6 \\
\hline $08 / 25 / 15$ & 17:00:00 & 1,350 & 808 & 3.3 \\
\hline $09 / 25 / 15$ & 09:30:00 & 1,820 & 843 & 3.0 \\
\hline $11 / 13 / 15$ & $11: 45: 00$ & 1,370 & 992 & 4.2 \\
\hline $11 / 19 / 15$ & 10:00:00 & 1,890 & 860 & 3.7 \\
\hline $06 / 17 / 16$ & $11: 30: 00$ & 2,840 & 569 & 2.2 \\
\hline $07 / 21 / 16$ & $10: 15: 00$ & 1,840 & 822 & 3.3 \\
\hline $08 / 11 / 16$ & $14: 30: 00$ & 2,000 & 811 & 3.6 \\
\hline $08 / 23 / 16$ & $10: 45: 00$ & 1,620 & 891 & 3.8 \\
\hline $9 / 14 / 2016$ & $10: 15: 00$ & 1,880 & 871 & 3.7 \\
\hline
\end{tabular}


Table 2.2. Calibration data for dissolved-selenium trend analysis at U.S. Geological Survey streamflow-gaging station 09152500Gunnison River near Grand Junction (Whitewater) for water years 1986-2016.

$\left[\mathrm{ft}^{3} / \mathrm{s}\right.$, cubic foot per second; daily mean specific conductance in microsiemens per centimeter at 25 degrees Celsius $\left(\mu \mathrm{S} / \mathrm{cm}\right.$ at $\left.25^{\circ} \mathrm{C}\right) ; \mu \mathrm{g} / \mathrm{L}$, microgram per liter]

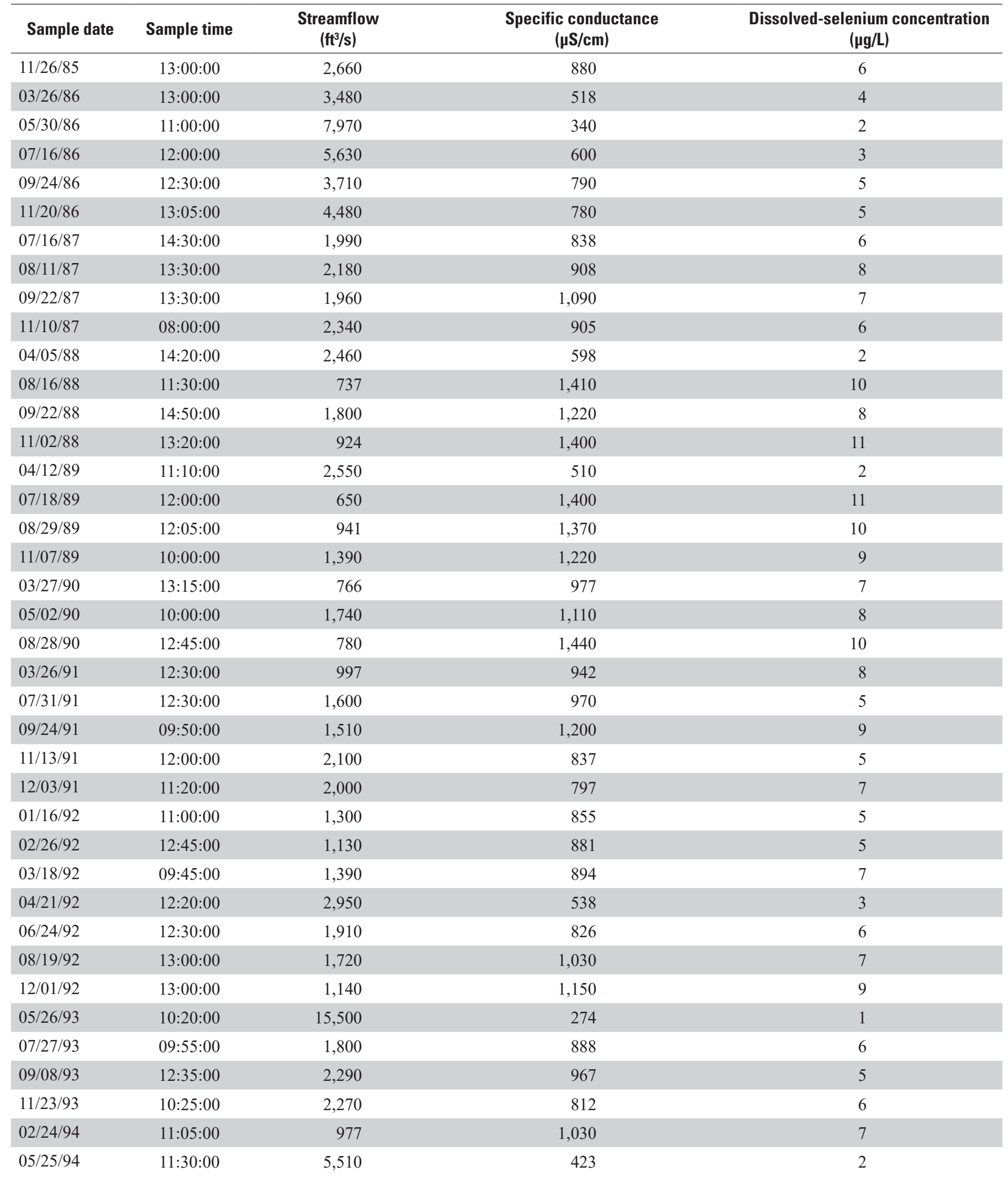


Table 2.2. Calibration data for dissolved-selenium trend analysis at U.S. Geological Survey streamflow-gaging station 09152500Gunnison River near Grand Junction (Whitewater) for water years 1986-2016.-Continued

$\left[\mathrm{ft} / \mathrm{s}\right.$, cubic foot per second; daily mean specific conductance in microsiemens per centimeter at 25 degrees Celsius $\left(\mu \mathrm{S} / \mathrm{cm}\right.$ at $\left.25^{\circ} \mathrm{C}\right) ; \mu \mathrm{g} / \mathrm{L}$, microgram per liter]

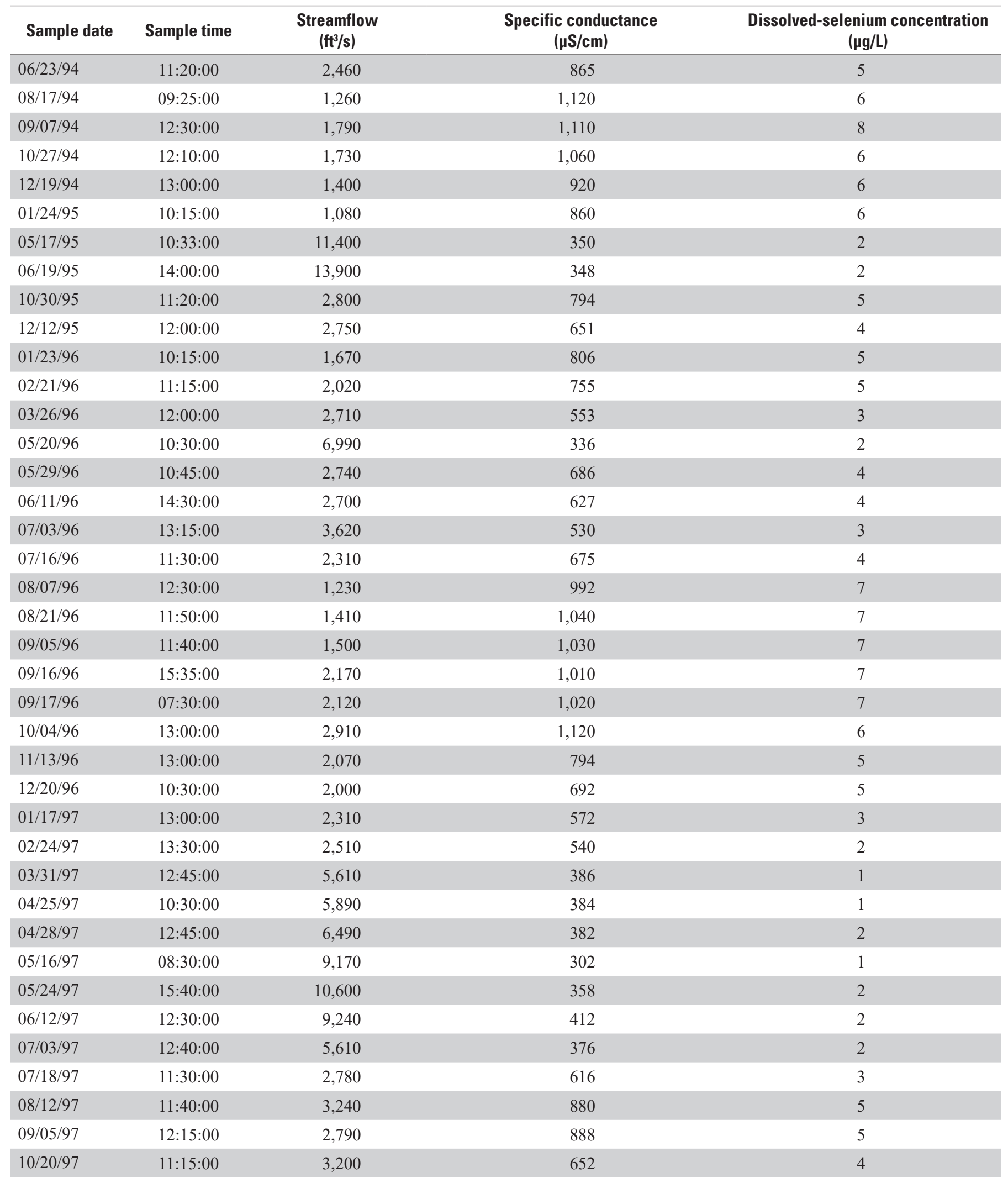


Table 2.2. Calibration data for dissolved-selenium trend analysis at U.S. Geological Survey streamflow-gaging station 09152500Gunnison River near Grand Junction (Whitewater) for water years 1986-2016.-Continued

$\left[\mathrm{ft}^{3} / \mathrm{s}\right.$, cubic foot per second; daily mean specific conductance in microsiemens per centimeter at 25 degrees Celsius $\left(\mu \mathrm{S} / \mathrm{cm}\right.$ at $\left.25^{\circ} \mathrm{C}\right) ; \mu \mathrm{g} / \mathrm{L}$, microgram per liter]

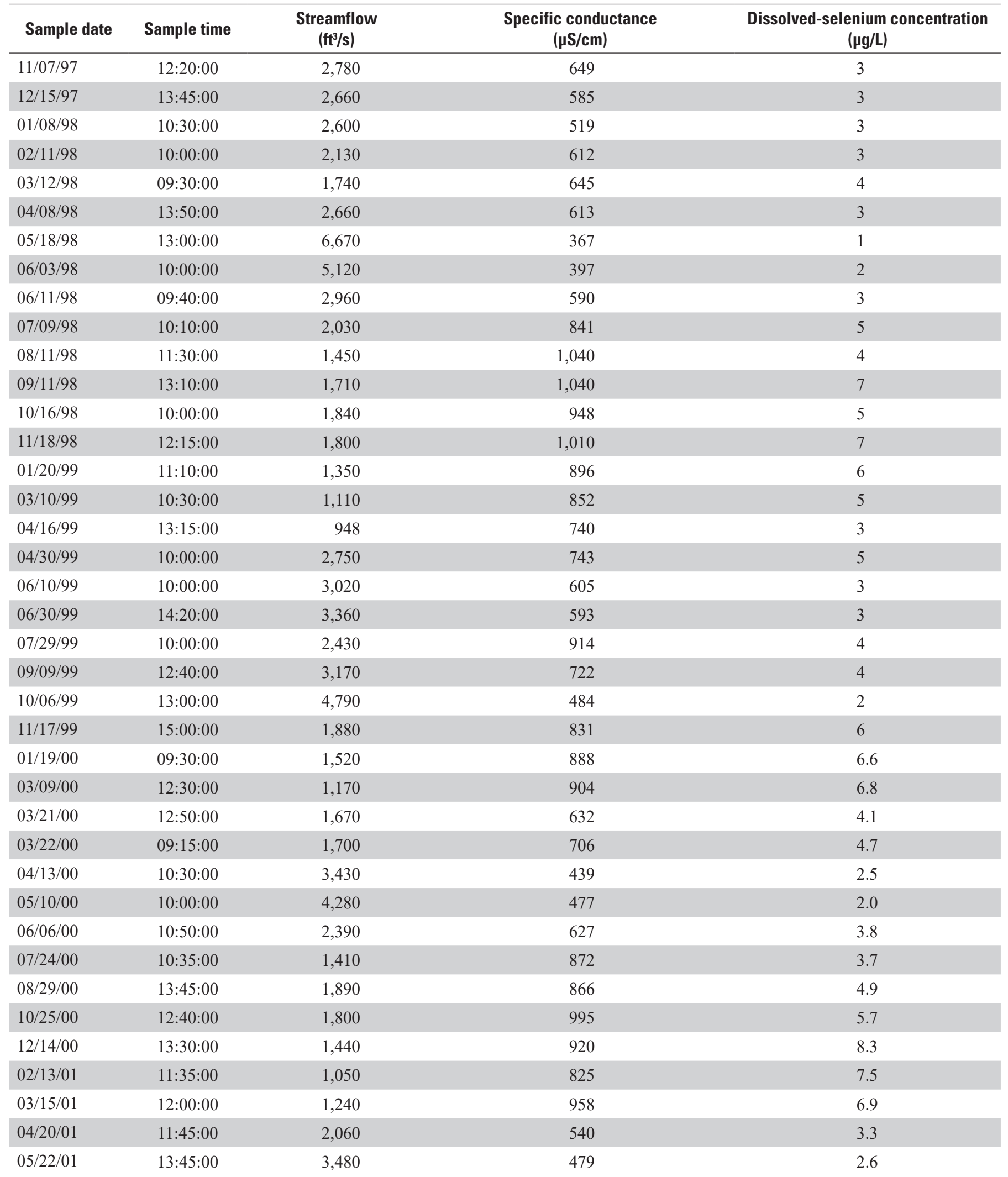


Table 2.2. Calibration data for dissolved-selenium trend analysis at U.S. Geological Survey streamflow-gaging station 09152500Gunnison River near Grand Junction (Whitewater) for water years 1986-2016.—Continued

$\left[\mathrm{ft}^{3} / \mathrm{s}\right.$, cubic foot per second; daily mean specific conductance in microsiemens per centimeter at 25 degrees Celsius $\left(\mu \mathrm{S} / \mathrm{cm}\right.$ at $\left.25^{\circ} \mathrm{C}\right) ; \mu \mathrm{g} / \mathrm{L}$, microgram per liter]

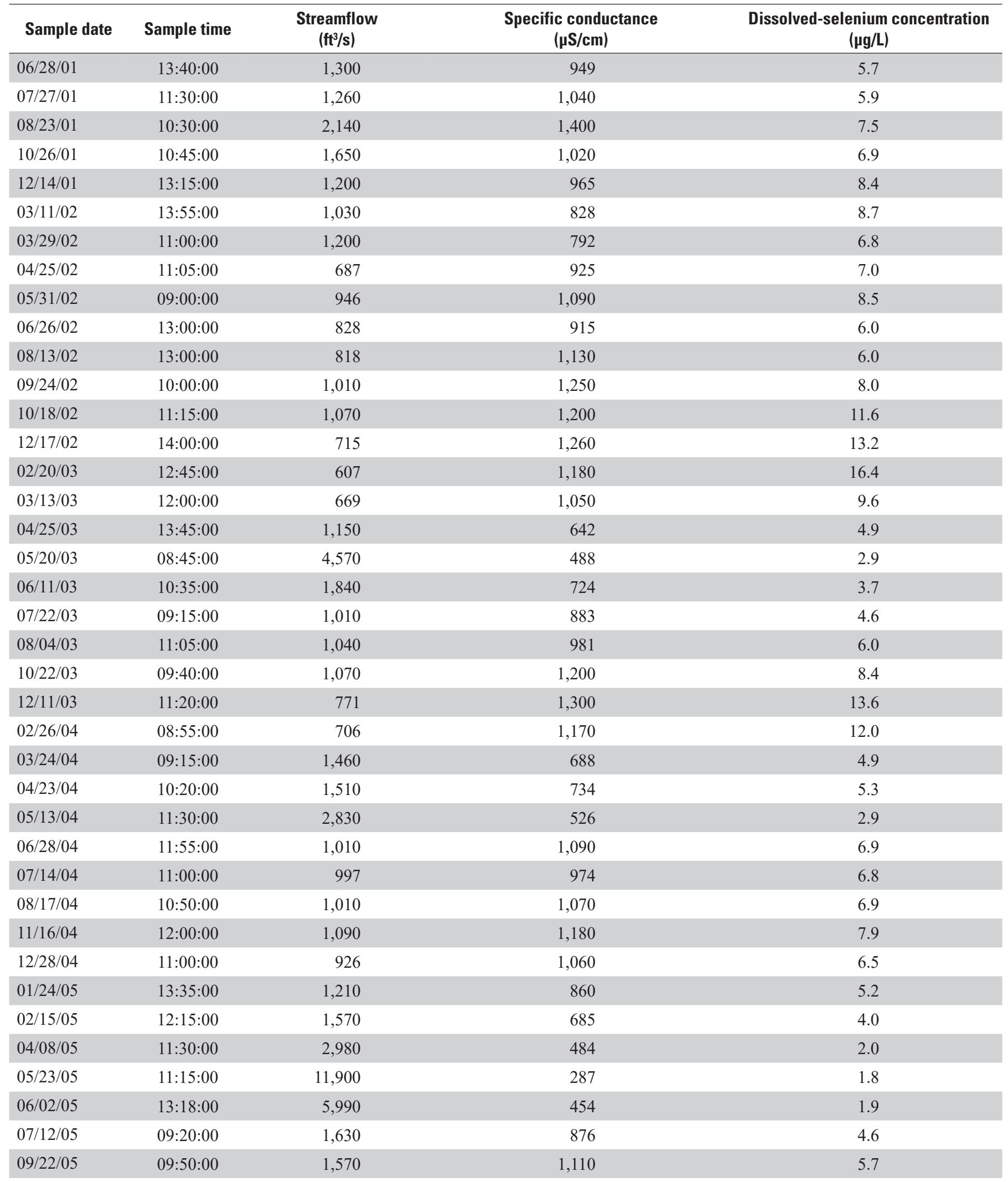


Table 2.2. Calibration data for dissolved-selenium trend analysis at U.S. Geological Survey streamflow-gaging station 09152500Gunnison River near Grand Junction (Whitewater) for water years 1986-2016._-Continued

$\left[\mathrm{ft}^{3} / \mathrm{s}\right.$, cubic foot per second; daily mean specific conductance in microsiemens per centimeter at 25 degrees Celsius $\left(\mu \mathrm{S} / \mathrm{cm}\right.$ at $\left.25^{\circ} \mathrm{C}\right) ; \mu \mathrm{g} / \mathrm{L}$, microgram per liter]

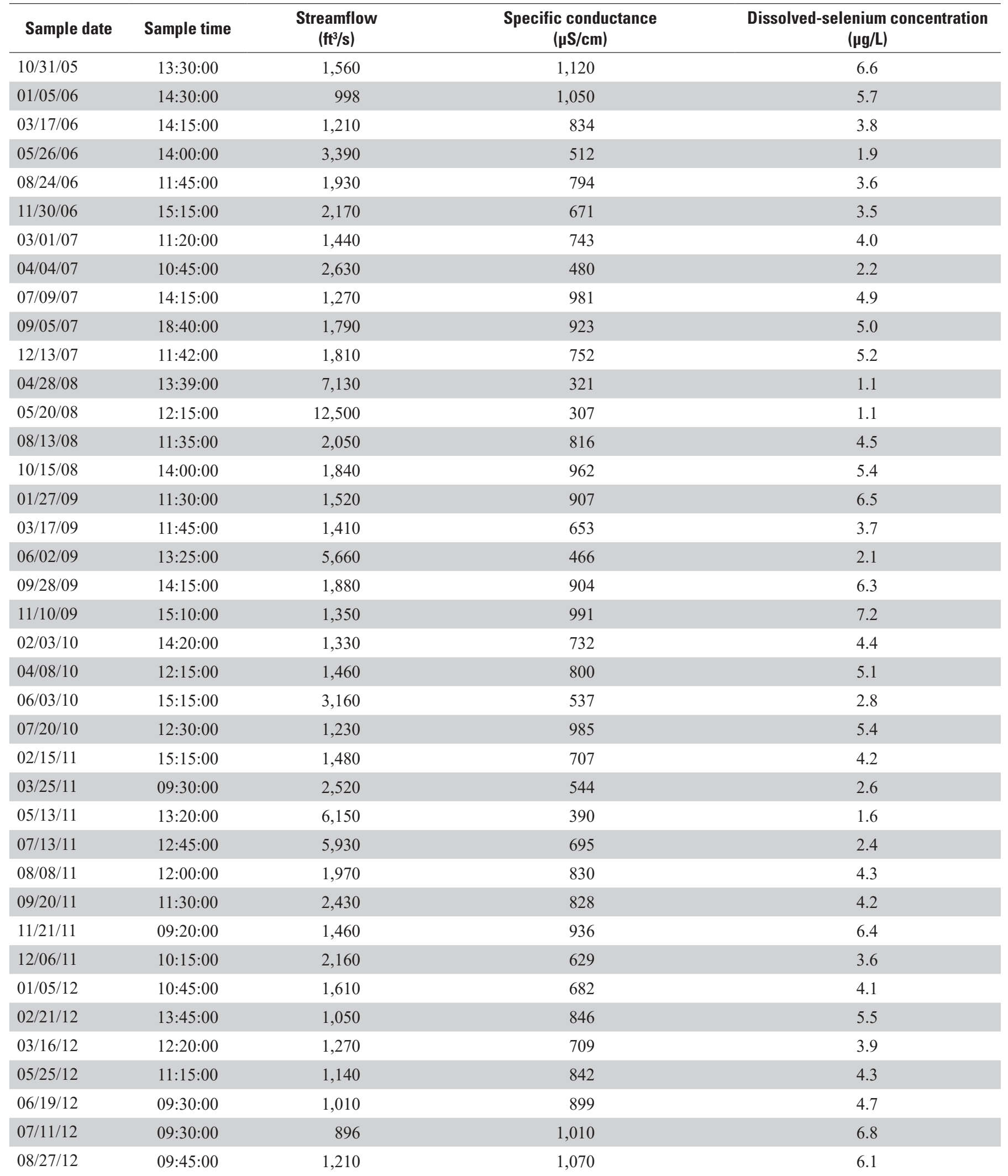


Table 2.2. Calibration data for dissolved-selenium trend analysis at U.S. Geological Survey streamflow-gaging station 09152500Gunnison River near Grand Junction (Whitewater) for water years 1986-2016.-Continued

$\left[\mathrm{ft} / \mathrm{s}\right.$, cubic foot per second; daily mean specific conductance in microsiemens per centimeter at 25 degrees Celsius $\left(\mu \mathrm{S} / \mathrm{cm}\right.$ at $\left.25^{\circ} \mathrm{C}\right) ; \mu \mathrm{g} / \mathrm{L}$, microgram per liter]

\begin{tabular}{|c|c|c|c|c|}
\hline Sample date & Sample time & $\begin{array}{c}\text { Streamflow } \\
\left(\mathrm{ft}^{3} / \mathbf{s}\right)\end{array}$ & $\begin{array}{c}\text { Specific conductance } \\
(\mu \mathrm{S} / \mathrm{cm})\end{array}$ & $\begin{array}{c}\text { Dissolved-selenium concentration } \\
(\mu \mathrm{g} / \mathrm{L})\end{array}$ \\
\hline $10 / 24 / 12$ & 09:45:00 & 991 & 1,210 & 7.0 \\
\hline $11 / 20 / 12$ & $12: 15: 00$ & 859 & 1,140 & 7.0 \\
\hline $01 / 16 / 13$ & 10:00:00 & 673 & 1,100 & 6.4 \\
\hline $02 / 20 / 13$ & 10:00:00 & 649 & 1,060 & 6.1 \\
\hline $04 / 23 / 13$ & 14:00:00 & 718 & 991 & 6.5 \\
\hline $05 / 17 / 13$ & 15:00:00 & 3,360 & 460 & 2.3 \\
\hline $07 / 23 / 13$ & $10: 15: 00$ & 1,080 & 979 & 4.2 \\
\hline $08 / 09 / 13$ & 14:30:00 & 1,320 & 1,000 & 4.5 \\
\hline $09 / 05 / 13$ & 12:00:00 & 1,130 & 1,030 & 4.7 \\
\hline $12 / 17 / 13$ & 13:30:00 & 885 & 1,060 & 6.0 \\
\hline $03 / 07 / 14$ & $13: 15: 00$ & 968 & 929 & 5.6 \\
\hline $04 / 15 / 14$ & 12:00:00 & 2,540 & 497 & 2.3 \\
\hline $05 / 28 / 14$ & $11: 15: 00$ & 6,020 & 447 & 1.9 \\
\hline $06 / 17 / 14$ & $12: 15: 00$ & 8,110 & 345 & 1.1 \\
\hline $08 / 14 / 14$ & $12: 30: 00$ & 1,790 & 857 & 4.0 \\
\hline 09/10/14 & $12: 45: 00$ & 2,330 & 1,030 & 5.2 \\
\hline $09 / 23 / 14$ & 10:30:00 & 1,820 & 1,020 & 5.2 \\
\hline $10 / 30 / 14$ & 13:00:00 & 1530 & 955 & 3.9 \\
\hline $12 / 11 / 14$ & $14: 00: 00$ & 1440 & 811 & 4.2 \\
\hline $02 / 20 / 15$ & $13: 15: 00$ & 1050 & 804 & 4.0 \\
\hline $04 / 08 / 15$ & 14:30:00 & 1210 & 618 & 3.0 \\
\hline $05 / 21 / 15$ & 13:30:00 & 3400 & 576 & 2.6 \\
\hline $06 / 24 / 15$ & 09:45:00 & 9140 & 316 & 0.9 \\
\hline $07 / 08 / 15$ & 09:30:00 & 2990 & 625 & 2.5 \\
\hline $08 / 10 / 15$ & 09:15:00 & 1570 & 884 & 3.6 \\
\hline $08 / 25 / 15$ & 17:00:00 & 1350 & 808 & 3.3 \\
\hline $09 / 25 / 15$ & 09:30:00 & 1820 & 843 & 3.0 \\
\hline $11 / 13 / 15$ & $11: 45: 00$ & 1370 & 992 & 4.2 \\
\hline $11 / 19 / 15$ & 10:00:00 & 1890 & 860 & 3.7 \\
\hline $12 / 10 / 15$ & $14: 45: 00$ & 1220 & 903 & 4.2 \\
\hline $03 / 24 / 16$ & 14:30:00 & 1600 & 702 & 2.8 \\
\hline $04 / 21 / 16$ & 11:30:00 & 2350 & 502 & 2.1 \\
\hline $05 / 05 / 16$ & 00:22:00 & 2740 & 520 & 2.1 \\
\hline $05 / 11 / 16$ & 10:00:00 & 5310 & 433 & 1.6 \\
\hline $06 / 14 / 16$ & 09:15:00 & 3610 & 540 & 2.0 \\
\hline $06 / 17 / 16$ & 11:30:00 & 2840 & 569 & 2.2 \\
\hline $07 / 21 / 16$ & 10:15:00 & 1840 & 822 & 3.3 \\
\hline $08 / 11 / 16$ & 14:30:00 & 2000 & 811 & 3.6 \\
\hline $08 / 23 / 16$ & 10:45:00 & 1620 & 891 & 3.8 \\
\hline $09 / 14 / 16$ & 10:15:00 & 1880 & 871 & 3.7 \\
\hline
\end{tabular}





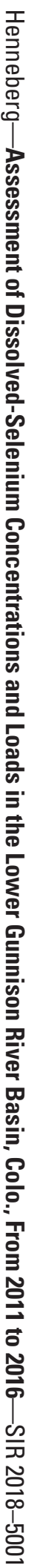

